\title{
Doğu Karadeniz'in Geleneksel Yapı Kültürüne Yapı Ustaları Üzerinden Bütüncül Bir Değerlendirme
}

\section{A Holistic Assessment of the Traditional Building Culture Among Building Masters in The Eastern Black Sea Region}

\section{Özlem Karakul ${ }^{*} \mathbb{B}$}

\section{Öz}

Bu çalışmanın amacı, yapı ustalarının kullandıkları yapım teknikleri, malzeme ve yapma biçimlerini inceleyerek Doğu Karadeniz Bölgesi geleneksel yapı kültürü üzerine bütüncül bir değerlendirme yapmaktır. Çalışma kapsamında, bölgesel konut yapım teknikleri, literatür araştırması verileri ile yapı ustalarından edinilen bilgiler doğrultusunda ele alınarak geleneksel mimari hem somut hem de somut olmayan değerleri açısından incelenmektedir. Çalışma yöntemi, literatür araştırması ve belgesellerde sunulan yapı ustalarıyla yapılmış mülakatların birlikte değerlendirilmesi ve elde edilen verilerin mimari çizimler üzerine aktarılmasından oluşmaktadır. Yapı ustalarını konu alan belgesel araştırmaları kapsamında, Süha Arın'ın 1986'da hazırladığı Karadeniz Geleneksel konutları ve ustalarını konu alan Sisler Kovulunca Belgeseli ile TRT tarafından 2005 yılında yayınlanan Derin Kökler Belgeseli'nin Doğu Karadeniz Evleri’ni konu alan 81. bölümü incelenmiştir. Literatür verileri ve belgesellerden elde edilen bilgiler, yapı ustalarının kullandıkları yapım teknikleri, malzeme ve araçların anlaşılması ve inşa süreciyle ilgili uygulamalar ve kuralların ortaya konulması, inşa sürecinin somut ve somut olmayan değerlerinin birlikte belgelenmesi amacıyla değerlendirilmiştir. Literatür verileri ve belgesellerden elde edilen bilgiler doğrultusunda, Doğu Karadeniz geleneksel mimarisinin inşa sürecine yönelik üç boyutlu çizimler hazırlanarak hem yapı ölçeğinde hem de uygulama detayları üzerinde ustaların farklı teknikleri uygulama biçimleri gösterilmiştir.

\section{Anahtar Kelimeler}

Geleneksel mimari, yapı kültürü, yapı ustaları, Doğu Karadeniz Bölgesi

\begin{abstract}
This study conducted a holistic assessment on the traditional building culture of the Eastern Black Sea region by investigating the construction techniques, materials, and methods among building masters. For this purpose, by examining regional building construction techniques and the data from the literature research, traditional architecture was investigated in terms of both its tangible and intangible values. Additional data was obtained from a series of interviews with the builders, architectural drawings, and two documentaries: a 1986 documentary by Süha Arın titled Sisler Kovulunca, which focused on Eastern Black Sea traditional houses and a sample of building masters; and a 2005 documentary by the Turkish Radio and Television Corporation called Derin Kökler, which focused on traditional buildings of the Eastern Black Sea region. All the data was then evaluated in order to document the tangible and intangible values of the construction processes of the builders, thus revealing their practices and rules related to such work. Moreover, three-dimensional drawings related to the construction process of the Eastern Black Sea traditional architecture were prepared to highlight the implementation of the different techniques by the building masters, both on the building scale and the application details.
\end{abstract}

\section{Keywords}

Traditional architecture, building culture, building masters, Eastern Black Sea region

* Sorumlu Yazar: Özlem Karakul (Doç. Dr), Selçuk Üniversitesi, Güzel Sanatlar Fakültesi, Konya, Türkiye. E-posta: karakulozlem@gmail.com, ORCID: 0000-0003-0874-6088

Atıf: Karakul, Ozlem. "Doğu Karadeniz'in Geleneksel Yapı Kültürüne Yapı Ustaları Üzerinden Bütüncül Bir Değerlendirme." Art-Sanat, 16(2021): 381-407. https://doi.org/10.26650/artsanat.2021.16.0013 


\section{Extended Summary}

In the Eastern Black Sea region, which has had human settlements since ancient times, the wood masonry and timber frame buildings are indicators of the forest density of the region as well as the development of the woodworking skills of the building masters from the past to the present. However, due to the low moisture resistance of the wood, many old buildings have not survived. Thus, it is important to examine the construction techniques of the traditional houses in the Eastern Black Sea region, with particular focus on the buildings in the settlements on the east side of Sinop.

The traditional houses of the Eastern Black Sea Region exhibit a unique wooden construction tradition with their local characteristics. The most significant elements constituting the traditional residential architecture in the region are the natural, economic and socio-cultural structure. The abundant rainy climate, extremely sloping topography, locally accessible materials (wood and stone), settlement patterns put forward with their impacts on the materials used and construction systems. In the region, the economic and social structure particularly shows its effects mainly on the interior design and plan typology of the buildings. The traditional houses of the Eastern Black Sea Region are built with a mixed system in which wooden masonry technique is used on the walls and stone masonry technique is used in the ground, underground and basement parts.

Traditional houses in the Eastern Black Sea region, as in other traditional settlements in Anatolia, have been built by building masters in accordance with environmental conditions, local material possibilities, and user requirements, based on traditional knowledge and skills. Meanwhile, rural architecture has been built by building masters through a process in which they transfer their knowledge, skills, and techniques by using local materials and tools, considering the environmental conditions and cultural practices. In this regard, it is significant to document the cultural and physical aspects of rural architecture, while considering the development of correct and holistic approaches for its protection. While the protection of the physical qualities of rural architecture, such as the built environment and settlement features, can be evaluated within the scope of "tangible cultural heritage," the protection of cultural characteristics, including the cultural practices and expressions carried out by the building masters, must be evaluated within the scope of "intangible cultural heritage."

The term "traditional crafts or handicrafts" has been defined at the UNESCO 2003 Convention as one of the domains in which intangible cultural heritage is related. The practices, knowledge, and skills of the building masters (i.e., the creators of traditional architecture) have also been evaluated within the scope of "traditional craftsmanship," while other studies have documented and protected such as aspects as intangible cultural heritage elements. Such elements include the techniques, methods, skills, 
and craftsmanship of the building masters, or in this case, those of the Anatolian rural building tradition and the transfer of such knowledge to new generations.

The conservation of traditional craftsmanship necessitates providing an accurate documentation, transmission from generation to generation and the continuity of the practices carried out by practitioner craftsmen. The accuracy of documentation can be achieved by understanding craftsmanship holistically, considering both its tangible and intangible aspects. The technology and the knowledge of the local craftsmen, have the formative power on the intangible values of traditional craftsmanship concretized mainly on the craft products in a historic environment. The intangible values of traditional craftsmanship are constituted by techniques and know-how, methods, skills, craftmanship and cultural expressions, various meanings, symbols, reflected over the craft product particular to the place. The tangible values of traditional craftsmanship are constituted by the use of materials, tools, production details in craft products, spatial characteristics and architectural elements.

Thus, this study conducted a holistic assessment on the traditional building culture of the Eastern Black Sea region by investigating the construction techniques, materials, and construction methods used by building masters. For this purpose, by examining regional building construction techniques and the data from the literature research, traditional architecture was investigated in terms of both its tangible and intangible values. Additional data was obtained from a series of interviews with the builders, architectural drawings, and two documentaries: a 1986 documentary by Süha Arın titled Sisler Kovulunca, which focused on Eastern Black Sea traditional houses and a sample of building masters; and a 2005 documentary by the Turkish Radio and Television Corporation called Derin Kökler, which focused on traditional buildings of the Eastern Black Sea region. All the aforementioned data was then evaluated in order to document the tangible and intangible values of the construction processes of the builders, thus revealing their practices and rules related to such processes. Moreover, three-dimensional drawings regarding the construction process of the Eastern Black Sea traditional architecture were prepared to highlight the implementation of the different techniques by the building masters, both on the building scale and the application details. 


\section{Giriş}

Antik dönemlerden beri insan yerleşmeleri barındırdığı bilinen Doğu Karadeniz Bölgesi’nde ahşap yığma ve çatma yapıların yoğunluğu, geçmişten günümüze bölgenin orman yoğunluğunun ve ustaların ahşabı işleme becerilerinin gelişmişliğinin de göstergesidir ${ }^{1}$. Ahşabın neme karşı dayanımının düşük olması sebebiyle, eski yapıların birçoğu günümüze ulaşamamış, dolayısıyla mimari literatür içindeki incelemeler, yalnızca günümüze ulaşan sınırlı sayıdaki yapılar üzerinden ele alınmıştır. Bu çalışma, Doğu Karadeniz Bölgesi'nin geleneksel konutlarının yapım tekniklerini, literatür verileri ile belgesellerde bulunan yapı ustalarıyla yapılan görüşmeler üzerinden inceleyerek yapı kültürünün bütüncül bir değerlendirmesini yapmayı amaçlamaktadır.

Geleneksel yapı kültürünün bütüncül değerlendirilmesi için mimari özelliklerle birlikte yapı ustalarının kullandıkları yapım teknikleri, malzemeleri, aletleri ve yapım yöntemleri de araştırılmalıdır. Çalışma kapsamında yöresel yapım tekniklerinin ele alındığ 1 literatür araştırmasından elde edilen veriler ile belgesellerde bulunan yapı ustalarıyla yapılan görüşmelerden elde edilen bilgiler dikkate alınarak geleneksel mimari hem somut hem de somut olmayan değerleri açısından değerlendirilmiştir. Çalışmanın yöntemi, belgesellerde sunulan yapı ustalarıyla yapılan görüşmeler ve literatür araştırması verilerinin birlikte değerlendirilmesi ve mimari çizimler üzerine aktarılmasından oluşmaktadır. Yapı ustaları ile ilgili belgesel araştırmaları kapsamında, Süha Arın tarafından 1986 yılında yapılan Doğu Karadeniz geleneksel evleri ve ustalarını konu alan Sisler Kovulunca ${ }^{2}$ belgeseli ile TRT'nin yapımcılı̆̆ını üstlendiği, 2005 yılında hazırlanmış Derin Kökler ${ }^{3}$ adlı belgesel filmin 81. bölümü incelenmiştir. Elde edilen bilgiler doğrultusunda Doğu Karadeniz'in geleneksel mimarisinin yapım sürecine ilişkin üç boyutlu çizimler hazırlanmış, ustalar tarafından uygulanan farklı tekniklerin uygulama yöntemleri hem yapı ölçeğinde hem de uygulama detaylarında gösterilecek şekilde düzenlenmiştir.

Doğu Karadeniz Bölgesi'ndeki geleneksel konutlar, Anadolu'daki geleneksel yerleşimlerde olduğu gibi, yapı ustaları tarafından çevresel koşullar, yöresel malzeme olanakları ve kullanıcı gereksinimlerine uygun olarak gelenek içinde sürdürülen bilgi ve becerilerle inşa edilmişlerdir. Kırsal mimari, yapı ustalarının çevresel koşullar ile gelenek içinde sürdürülen kültürel pratik ve anlatımları gözeterek, yöresel malzeme ve araçlar kullanarak, bilgi, beceri ve tekniklerini aktardıkları bir süreç-

1 Reşat Sümerkan, "Biçimlendiren Etkenler Açısından Doğu Karadeniz Kırsal Kesiminde Geleneksel Evlerin Yapı Özellikleri”" (Doktora Tezi, Karadeniz Teknik Üniversitesi, 1990), 52.

2 Süha Arın, Sisler Kovulunca: Eski Evler, Eski Ustalar, Doğu Karadeniz, belgesel film, MTV, 1986. https:// www.youtube.com/watch? $\mathrm{v}=\mathrm{Ngu}-6 \mathrm{DgkEFg}$, erişim 28 Haziran 2021.

3 Muhammed Salih Şimşek, Derin Kökler-81.Bölüm, Belgesel film, TRT, 2005. https://www.youtube.com/ watch?v=0C63Qx_mw9k, erişim 28 Haziran 2021.

4 Özlem Karakul, "A Conservation Approach to the Knowledge and Skills of Traditional Building Masters", Milli Folklor 107 (2015), 149-160. 
le inşa edilmektedirler. Bu süreçte inşa edilen kırsal yapıların kültürel ve fiziksel yönleriyle bir bütün olarak belgelenmesi, korunmalarına yönelik doğru ve bütüncül yaklaşımların geliştirilmesi açısından önemlidir5. Kırsal mimarinin yapılı çevre ve yerleşim özellikleri gibi fiziki niteliklerinin korunması, "somut kültürel miras" kapsamında değerlendirilirken, kültürel pratik ve anlatımlar, yapı geleneği içinde yapı ustaları tarafından sürdürülen bilgi ve uygulamalar ve yaşam biçimleri gibi kültürel niteliklerinin korunması ise "somut olmayan kültürel miras"6 kapsamında değerlendirilmesi gereken konulardır?.

Kırsal yerleşimlerde, yapı ustalarının yerel yapı malzemeleri ve geleneksel yapım tekniklerini kullanımıyla tanımlanabilen geleneksel yapım yöntemleri, yöresel yapı kültürünün özgünlüğünü de oluşturmaktadır ${ }^{8}$. Nesilden nesile aktarılan geleneksel yapım yöntemlerinin çağdaş yapı teknolojilerinin geliştiği günümüz koşullarında sürdürülebilirliği, yapı kültürü uygulayıcılarının etkinliklerine devam etmesiyle olanaklıdır. Bu anlamda, yöresel yapı kültüründe geleneksel olarak sürdürülen bilgi ve uygulamaların da disiplinler arası bir yöntemle, somut ve somut olmayan yönleriyle belgelenmesi gereklidir.

Geleneksel mimaride somutlaşan "geleneksel ustalıklar" ve yöresel yapı kültürünün yaratıcıları olan yapı ustalarının etkinlikleri, UNESCO Somut Olmayan Kültürel Mirasın Korunması Sözleşmesi'nde vurgulandığı gibi somut olmayan kültürel mirasın ilişkili olduğu alanlardan biridir. Yapı kültüründe geleneksel zanaatlar, ustaların becerilerini yansıtan mimarideki fiziki temsilleri yanında, yaşayanlar ve yapı ustalarının atfettiği anlamlardan oluşan anlatımsal özellikler taşımaktadır. "Yapı kültürü”"10 içinde incelenebilecek kırsal mimariye yansıyan somut olmayan kültürel miras unsurları, yapı ustalarının bilgisi ve kullandığı teknolojinin belirlediği teknikler, teknik bilgiler,

5 Özlem Karakul, "Kerpiç Mimaride Bezeme”, Yapı Dergisi 447, (2019), 64-71; Özlem Karakul, “An Integrated Approach to Conservation Based on The Interrelations of Tangible and Intangible Cultural Properties", METU Journal of The Faculty of Architecture 28/2 (2011), 106.

6 UNESCO 2003 Somut Olmayan Kültürel Mirasın Korunması Sözleşmesi'nde yapılan tanıma göre somut olmayan kültürel miras, "toplulukların, grupların ve kimi durumlarda bireylerin, kültürel miraslarının bir parçası olarak tanımladıkları uygulamalar, temsiller, anlatımlar, bilgiler, beceriler ve bunlara ilişkin araçlar, gereçler ve kültürel mekânlar” anlamına gelir.

7 Karakul, "An Integrated Approach to Conservation Based on The Interrelations of Tangible and Intangible Cultural Properties", 106.

8 Karakul, "A Conservation Approach to the Knowledge and Skills of Traditional Building Masters", 150; Özlem, Karakul, "An Integrated Methodology for the Conservation of Traditional Craftsmanship in Historic Buildings", International Journal of Intangible Heritage, 10 (2015), 137.

9 UNESCO 2003 Sözleşmesi'nde mirasin belirdiği alanlar olarak, "gösteri sanatları, toplumsal uygulamalar, ritüeller ve şölenler; doğa ve evrenle ilgili bilgi ve uygulamalar ve el sanatları geleneği” belirtilmektedir.

10 Karakul, kültürü, yapılı çevreye yansıma biçimlerine göre, "yaşama kültürü”, “yapı kültürü” ve "değer sistemleri” olarak üç grupta incelemektedir. Bk. Özlem Karakul, "An Integrated Approach to Conservation Based on The Interrelations of Tangible and Intangible Cultural Properties", METU Journal of The Faculty of Architecture 28/2 (2011), 105-125; Özlem Karakul, "Folk Architecture in Historic Environments: Living Spaces for Intangible Cultural Heritage", Milli Folklor 75 (2007): 151-163 
yöntemler, beceriler ve ustalıklardır ${ }^{11}$. Anadolu kırsal yapı geleneğinin uygulayıcıları olarak yerel ustaların bilgi, beceri, teknik ve yöntemlerinin belgelenmesi ve yeni nesillere aktarımı, geleneğin sürekliliği için zorunludur. Bu çalışma, Doğu Karadeniz Bölgesi geleneksel yapı kültürünü, somut ve somut olmayan değerleriyle bütüncül bir yaklaşımla incelemeyi amaçlamaktadır.

\section{Doğu Karadeniz Evlerinin Mimari Özellikleri}

Doğu Karadeniz Bölgesi geleneksel konutları, yerel özellikleriyle, kendine özgü bir ahşap yapı geleneği sergilemektedir. Bölgede geleneksel konut mimarisini oluşturan en önemli unsurlar, doğal, ekonomik ve sosyo-kültürel yapı olmakla birlikte, bunlar arasında, bol yağışlı iklim, aşırı eğimli topoğrafya, yerel erişilebilir malzemeler (ahşap ve taş), yerleşme biçimleri, kullanılan malzeme ve yapım sistemleri üzerindeki etkisi öne çıkmaktadır. Yöredeki yapılarda ekonomik ve sosyal yapı ise etkilerini ağırlıklı olarak iç mekân kurgusu ve plan tipolojisi üzerinde göstermektedir.

Doğu Karadeniz Bölgesi geleneksel konutları, genellikle evlerin tek tek ya da birkaç evlik kümeler şeklinde topoğrafyaya dağıldığı bir yerleşim düzenine sahiptir ${ }^{12}$ (G. 1). Çamlıhemşin Topluca Köyü’nden Ali Yağcı Usta, 87 adet konut inşa ettiğini, geleneksel konutların inşa edileceği yerin seçiminde, "kar ve tipiye karşı korunaklı olmasına, yapının konumlandığı zeminin kaymamasına, su almamasına" dikkat ettiklerini belirtmektedir ${ }^{13}$. Doğu Karadeniz Bölgesi'nin nemli iklimi, konut biçimlenmesinde ağırlıklı rol oynamaktadır. Yapıların havalandırılması ve hava akımlarının iç mekâna alınması için, yapı ustaları eğime oturan yapıların çevredeki ağaç boyundan yüksek olmasına dikkat ederek, büyük pencere boşlukları açılmasına ve çatıların yığma duvarlar üzerine uzun yarıklar açılmasına önem vermektedir ${ }^{14}$. Yapıların kütlesini saran geniş saçaklar, yapı duvarlarını yağmura karşı korurken, mimari dilde baskın bir eleman olarak ortaya çıkmaktadır ${ }^{15}$.

11 Mustafa Pultar, "A Structured Approach to Cultural Studies of Architectural Space", Culture and Space in the Home Environment, Critical Evaluations and New Paradigms (İstanbul: İstanbul Teknik Üniversitesi Mimar11k Fakültesi, 1997), 27-32; Nobuo Ito, "Intangible Cultural Heritage Involved in Tangible Cultural Heritage". ICOMOS 14th General Assembly and Scientific Symposium'da sunulan bildiri, Victoria Falls, Zimbabwe, 27-31 Ocak 2003. http://openarchive.icomos.org/id/eprint/484/1/A3-2_-_Ito.pdf, erişim 28 Haziran 2021; Natsuko Akagawa ve Tiamsoon Sirisrisak, "Intangible Heritage in Urban Planning Process, Case Study: Chao Phraya Riverscape, Thailand", The 8th International Asian Planning Schools Association Congress'de sunulan bildiri, Malezya, 11-14 Eylül 2005.

12 Sümerkan, Biçimlendiren Etkenler Açısından Doğu Karadeniz Kırsal Kesiminde Geleneksel Evlerin Yapı Özellikleri, 59 .

13 Kaynak Kişi: Ali Yağcı, Süha Arın, Sisler Kovulunca: Eski Evler, Eski Ustalar, Doğu Karadeniz, Belgesel film, MTV, 1986. https://www.youtube.com/watch?v=Ngu-6DgkEFg, erişim 28 Haziran 2021.

14 Kemal Aran, Barınaktan Öte| Anadolu Kır Yapıları (Ankara: Tepe Mimarlık Kültürü Merkezi, 2000), 108. 15 Aran, Barınaktan Öte| Anadolu Kır Yapıları, 108. 


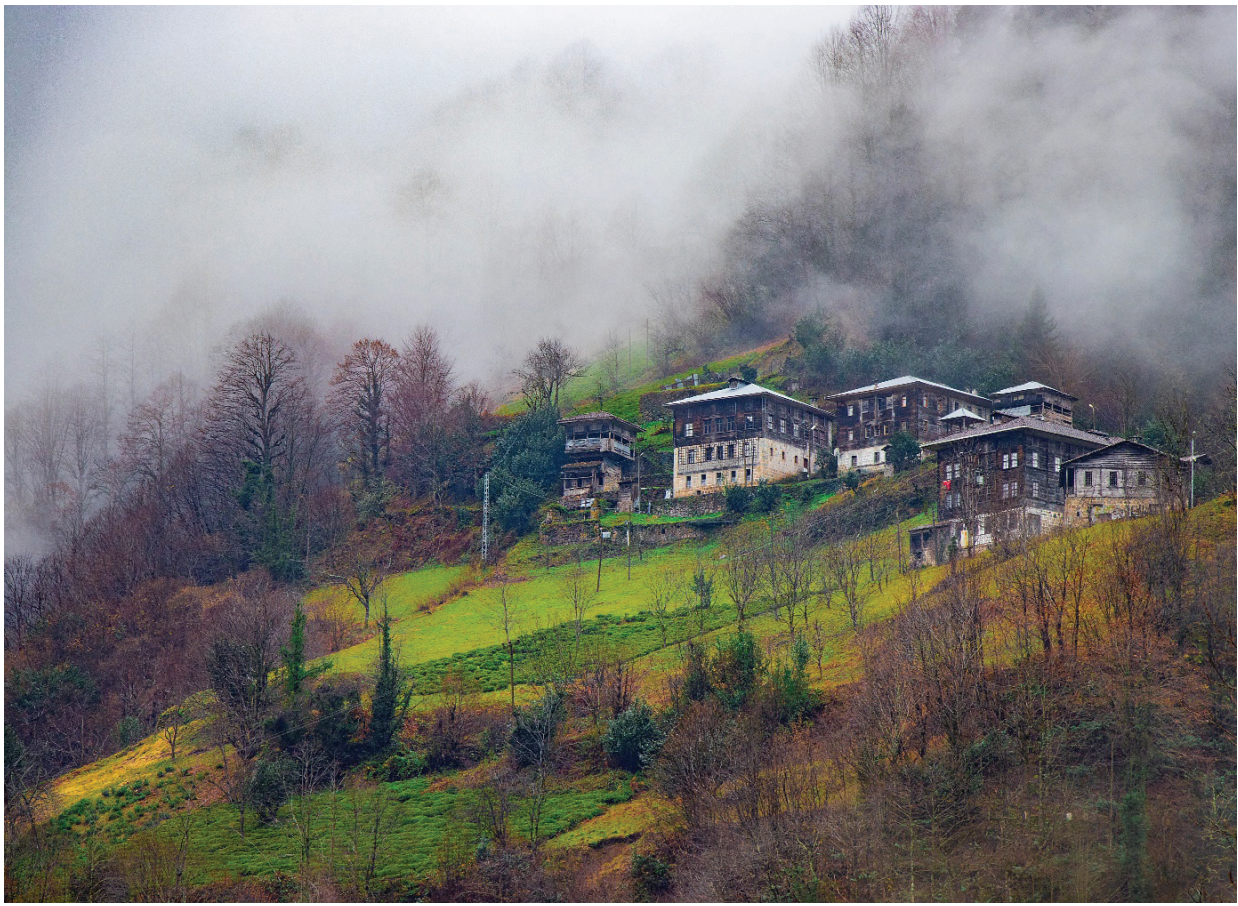

G. 1: Doğu Karadeniz Geleneksel Konutları Yerleşim Düzeni, Rize (Kaynak: Yüksel Aslan Arşivi)

Karadeniz geleneksel konutlarında iç mekân kurgusu, yapı ustaları tarafından yüzyıllardır sınanarak günümüze ulaşan geleneksel köy hayatının yansıması olarak gelişen plan şemasına dayanmaktadır ${ }^{16}$. Farklı bölgelerde, Hayat, Çardak ya da Salon adı verilen, ortak kullanım mekânı, plan kurgusunun merkezinde yer almakta, özel kullanım mekânı olarak kullanılan odalar ise, ailenin büyüklüğüne göre farklı sayıda olabilmektedir ${ }^{17}$.

Özgüner'in Salonlu ve Hayatlı olarak iki grupta incelediği geleneksel konut plan tiplerini, Sümerkan yöresel kullanım ve söylem farklılıklarını dikkate alarak, Salonlu, Basit Aşhaneli ve Hayatl Aşhaneli olarak üç grupta incelemektedir. ${ }^{18}$ Salonlu tip evlerde, giriş mekânı Salon olarak adlandırılmakta, hayatlı evlerde ise, Aşhane ve diğer servis mekânlarını kapsayan Hayat mekânı bulunmaktadır ${ }^{19}$. Aşhane, pişirme, yeme ve misafir ağırlama etkinlikler için kullanılan çok amaçlı bir mekândır ${ }^{20}$. Farklı

16 Orhan Özgüner, Köyde Mimari: Doğu Karadeniz (Ankara: Apa Ofset Basimevi, 1970), 10.

17 Özgüner, Köyde Mimari: Doğu Karadeniz, 10.

18 Sümerkan, Biçimlendiren Etkenler Açısından Doğu Karadeniz Kırsal Kesiminde Geleneksel Evlerin Yapı Özellikleri, 80 .

19 Özgüner, Köyde Mimari: Doğu Karadeniz, 60.

20 Sümerkan, Biçimlendiren Etkenler Açısından Doğu Karadeniz Kırsal Kesiminde Geleneksel Evlerin Yapı Özellikleri, 80 . 
yörelerde Hayat ve Aşhane mekânlarının kullanımlarının ve tipolojilerdeki etkilerinin değişebileceğini belirten Sümerkan, bu sebeple Özgüner'in ikili tipolojisini geliştirerek üç ana plan tipolojisi ortaya koymaktadır (G. 2). Geleneksel Doğu Karadeniz Evleri'nde, mutfak, kiler, ambar, çamaşırhane gibi servis mekânları çoğunlukla zemin ya da bodrum katta yer aldığından, plan tipolojisi üzerinde etkisi yoktur ${ }^{21}$.

Eve girildiğinde karşılaşılan ilk mekân olan hayat, ev halkının bir araya geldiği, pişirme ve yemek etkinliklerinin yapıldığı, odalara, depo ve kiler mekânlarına geçişin sağlandığı, çok amaçlı bir mekândır. Salon mekânının hayattan farkı ise yemek pişirme etkinliğini ve ocak mimari elemanını içermemesidir ${ }^{22}$. Salonlu evlerde, ayrı bir mekân olarak bulunan mutfak, ortak mekânın çevresinde yer alan oda kurgusunun dışında yer almaktadır. Odalarda, yüklük, dolap, gusülhane mimari elemanları bulunmaktadır ${ }^{23}$. Müslüm Usta ve İsmail Dilaver Usta, Karadeniz Evleri’nde “odaların pencerelerinin çoğunlukla demir parmaklıklı olduğunu, fakat bir odanın penceresine parmaklık yapmadıklarını, bu geleneğin nedeninin yangın sırasında kaçışı kolaylaştırmak"24 olduğunu vurgulamaktadır.

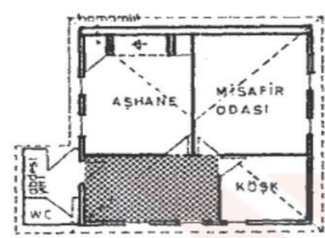

SALONLU

TIP

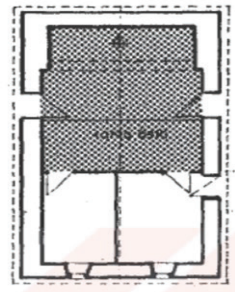

BASIT ASHANELI

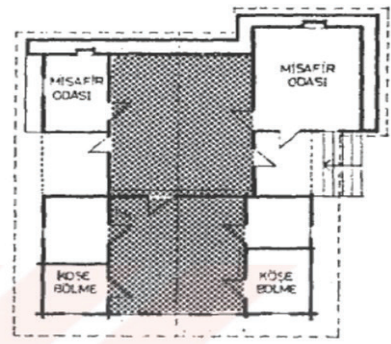

HAYATLI - ASTHANELI

G. 2: Doğu Karadeniz Evleri Plan Tipleri (Sümerkan, "Biçimlendiren Etkenler Açısından Doğu Karadeniz Kırsal Kesiminde Geleneksel Evlerin Yapı Özellikleri”, 81)

\section{Doğu Karadeniz Konutunda Malzeme Kullanımı ve Yapım Teknikleri}

\subsection{Malzeme Kullanımı}

\section{Ahşap}

Doğu Karadeniz Bölgesi'nin geleneksel konutlarının temel yapı malzemesi olan ahşap, duvar sistemlerinde, döşemelerde, doğramalarda, çatılarda ve donatılarda kul-

21 Seyfi Başkan, “Geleneksel Doğu Karadeniz Evleri”, Erdem: Atatürk Kültür Merkezi Dergisi 52 (2008), 51.

22 Özgüner, Köyde Mimari: Doğu Karadeniz, 60.

23 Başkan, "Geleneksel Doğu Karadeniz Evleri”, 51.

24 Kaynak Kişiler: Müslüm, İsmail Dilaver, Sisler Kovulunca, Belgesel film. 
lanılmaktadır ${ }^{25}$. Kolay bulunabilmesi ve işlenebilmesi sebebiyle, Doğu Karadeniz geleneksel konutlarının temel yapı malzemesi olan ahşap, ustaların kullandığı farklı tekniklerle, köprü, konut, cami gibi farklı yapı türlerinin inşasında, iç mekânlarda, mimari eleman ve bezeme yapımında tercih edilmektedir ${ }^{26}$. Ahşap ayrıca, levha hâlinde biçimlendirilerek çatı kaplama malzemesi olarak da değerlendirilmektedir ${ }^{27}$.

Ahşap, eski yapılarda geçme tekniğiyle, daha sonra kısmen geçme tekniği ile kısmen çivili birleştirme tekniği ile kullanılarak günümüze gelmiştir ${ }^{28}$. Ustaların, ağaçları "işlenebilme", "çalışma" ve "lif özellikleri" açısından deneyerek belirledikleri iyi cins ağaçlardan biri olan kestane, konutlarda en sık kullanılan ahşap türüdür ${ }^{29}$. Yağmura, rutubete, yangına ve böceklenmeye karşı dayanımı nedeniyle tercih edilen kestane ağacının maliyeti oldukça yüksektir ${ }^{30}$. Kestanenin temin edilemediği durumlarda ise pelit, çam, köknar, dişbudak, karaağaç, kayın ve ladin ağacı kullanılmaktadır ${ }^{31}$. Çamlıhemşin Topluca Köyü’nden 60 yaşındaki Ali Yağcı Usta, "şeftali ağacının da çok dayanıklı bir ağaç olduğunu, 100-200 sene dayanabildiğini ve bu nedenle bölgede tercih edildiğini”’32 belirtmektedir.

\section{Taş}

Konutlarda ikincil yapı malzemesi olan taş, bodrumlarda, eğimli arazilerde kalkan duvarlarında, nadiren bazı yapılarda, bir cephe duvarının tümünün örülmesinde, ahır ve depo yapılarının inşasında ve ahşap yapı sistemleri içinde dolgu malzemesi olarak kullanılmaktadır ${ }^{33}$. Doğu Karadeniz Bölgesi'nin, Akçaabat Söğütlü Deresi Vadisi, Maçka ve Araklı'da, yapı malzemesi olarak kullanılabilecek, işlemeye elverişli taşların bulunması sebebiyle bütünüyle taş duvarlı evlerde görülebilmektedir ${ }^{34}$. Yapı malzemesi olarak daha çok kalker esaslı taşlar ile andezit bazalt gibi sert taşlar tercih edilmektedir ${ }^{35}$. Kolay işlenemeyen sert taşlar, moloz taş duvar sisteminde, kolay işle-

25 Sümerkan, Biçimlendiren etkenler açısından Doğu Karadeniz kırsal kesiminde geleneksel evlerin yapı özellikleri, 60.

26 Özgüner, Köyde Mimari: Doğu Karadeniz, 8; Aran, Barınaktan Öte| Anadolu Kır Yapıları, 208.

27 Özgüner, Köyde Mimari: Doğu Karadeniz, 24; Burhan Oğuz, Türkiye Halkının Kültür Kökenleri-3: Inşa, Isıtma ve Aydınlatma Teknikleri, (İstanbul: Anadolu Aydınlanma Vakfı Yayınları, 2001), 338.

28 Özgüner, Köyde Mimari: Doğu Karadeniz, 22.

29 Özgüner, Köyde Mimari: Doğu Karadeniz, 22; Sümerkan, Biçimlendiren Etkenler Açısından Doğu Karadeniz Kırsal Kesiminde Geleneksel Evlerin Yapı Özellikleri, 60, 62.

30 Özgüner, Köyde Mimari: Doğu Karadeniz, 22; Sümerkan, Biçimlendiren Etkenler Açısından Doğu Karadeniz Kırsal Kesiminde Geleneksel Evlerin Yapı Özellikleri, 62.

31 Özgüner, Köyde Mimari: Doğu Karadeniz, 22; Sümerkan, Biçimlendiren Etkenler Açısından Doğu Karadeniz Kırsal Kesiminde Geleneksel Evlerin Yapı Özellikleri, 64.; Reşat, Sümerkan, "Gelenekselden Betonarmeye Trabzon Kırsal Mimarlığı”, Mimarlık 234/2 (1989), 83.

32 Kaynak Kişi: Ali Yağcı, Sisler Kovulunca, Belgesel film.

33 Özgüner, Köyde Mimari: Doğu Karadeniz, 23; Sümerkan, "Gelenekselden Betonarmeye Trabzon Kirsal Mimarlığı”, 83; Sümerkan, Biçimlendiren Etkenler Açısından Doğu Karadeniz Kırsal Kesiminde Geleneksel Evlerin Yapı Özellikleri, 64.

34 Sümerkan, "Gelenekselden Betonarmeye Trabzon Kırsal Mimarlığı”, 83.

35 Başkan, “Geleneksel Doğu Karadeniz Evleri”, 45; Sümerkan, Biçimlendiren Etkenler Açısından Doğu Karadeniz Kırsal Kesiminde Geleneksel Evlerin Yapı Özellikleri, 65. 
nebilen taşlar ise kesme taş tekniğiyle kullanılabilmektedir. Düzgün kesilmiş taşlar ise çoğunlukla, cephe kaplamaları, pencere kenarları ve bina köşeleri için ayrılmaktadır ${ }^{36}$. Ayrıca iç mekânlarda bulunan ocak, şömine ve bacalar da taştan yapılmaktadır ${ }^{37}$. Doğu Karadeniz evlerinde, nemi çok az tutan taşın kullanımı, yüksek nemli zemini neme dayanıksız ahşap kısımdan ayırmak için kullanılan en doğru yapı malzemesidir ${ }^{38}$.

\section{Pişmiş Toprak Yapı Malzemeleri: Tuğla ve Kiremit}

Geleneksel konutlarda kullanılan diğer bir yapı malzemesi olan tuğla kolay temin edilemediği için nadiren; alaturka kiremit ise çatıda "hartama" adı verilen ahşap kaplama kullanımı daha yaygın olduğundan sadece Rize ve Artvin çevresinde görülmektedir ${ }^{39}$.

\subsection{Yapım Teknikleri}

Ahşap malzemenin bolluğu ve kolay işlenebilmesi sebebiyle, Doğu Karadeniz Bölgesi'nde evler, çoğunlukla “ahşap çatma” ve "ahşap yığma” yapım teknikleri kullanılarak inşa edilmiştir ${ }^{40}$. Konut inşa süresinin uzunluğu sebebiyle, ahşap karkas sistem, kısa sürede yapının ve çatının inşa edilerek inşaatın korunumunu sağladığ için, bölge halkı tarafından kullanılmaktadır ${ }^{41}$. Çamlıhemşin Topluca Köyü'nde yapı ustası olarak çalışan, Ali Yağcı "havanın nemli olması nedeniyle ahşap yapım sistemlerinin tercih edildiğini, son yıllarda yaygınlaşan betonarme sistemlerin ise sağliklı olmadığını"42 belirtmektedir.

Doğu Karadeniz Bölgesi'nin geleneksel konutları, duvarlarda ahşap çatma ve yı̆̆ma tekniği ile zemin, zemin altı ve bodrum kısımlarında taş yığma tekniğinin kullanıldığ 1 karma bir sistemle inşa edilmektedir. Bu bakımdan, Doğu Karadeniz Bölgesi konutlarında kullanılan yapı sistemleri, yığma taban (zemin ve zemin altı, bodrum duvarları), ahşap çatma ya da yığma tekniğiyle inşa edilen duvarlar ve çatı olmak üzere üç bölümde incelenebilir.

36 Başkan, "Geleneksel Doğu Karadeniz Evleri”, 45.

37 Sümerkan, Biçimlendiren Etkenler Açısından Doğu Karadeniz Kırsal Kesiminde Geleneksel Evlerin Yapı Özellikleri, 64.

38 Sümerkan, Biçimlendiren Etkenler Açısından Doğu Karadeniz Kırsal Kesiminde Geleneksel Evlerin Yapı Özellikleri, 65 .

39 Sümerkan, Biçimlendiren Etkenler Açısından Doğu Karadeniz Kırsal Kesiminde Geleneksel Evlerin Yapı Özellikleri, 60 .

40 Özgüner, Köyde Mimari: Doğu Karadeniz.

41 Özgüner, Köyde Mimari: Doğu Karadeniz, 8.

42 Süha Arın, Sisler Kovulunca: Eski Evler, Eski Ustalar, Doğu Karadeniz, Belgesel film, MTV. 


\subsubsection{Yığma Taban- Temel ve Zemin Kat Duvarları}

Doğu Karadeniz geleneksel konutunda, yığma taş duvar sistemi genellikle temel duvarlarında, bodrum katlarında ve zemin katların eğimli zemine gömülü arka duvarlarında, nadiren ise yapının bir duvarı boyunca görülmektedir ${ }^{43}$. Dere yataklarından toplanan çakıl taşların büyükleri dolgu malzemesi olarak, küçükleri ise yer kaplamasında değerlendirilmektedir ${ }^{44}$. Çakıl taşları dışında ocaklardan çıkarılan suya dayanık11, kolay işlenebilen taşlar da konutlarda kullanılmaktadı ${ }^{45}$. Bu taşlar arasında, kolay işlenebilen kalker esaslı taşlar ile andezit, bazalt gibi daha sert taşlar bulunmaktadır ${ }^{46}$. Taş, genellikle moloz taş görünüşünde kuru veya harçla örülerek kullanılmakla birlikte ${ }^{47}$ bazı örneklerde kesme taş duvar tekniği de görülmektedir.

\subsubsection{Ahşap Yapım Sistemleri}

Geleneksel konutların beden duvarları, yığma taş duvarlar üzerinde, ahşap yığma ile ahşap çatma teknikleri kullanılarak inşa edilmektedir.

\section{Ahşap Yı̆̆ma Tekniği}

Beden duvarlarının inşasında kullanılan ahşap yığma sistemi, dikmeler olmaksızın tahta, tomruk ve/veya kütüklerin köşelerde geçmelerle yatay olarak, üst üste bindirilerek inşa edilmesiyle kurulan taşıyıcı sistemlerdir ${ }^{48}$ (G. 3, G. 4, G. 5). Bu sistem içinde, yükler, her ahşap elemandan bir alttakine geçerek zemine iletilmektedir. Ahşap yığma tekniğinde, 2 ile $5 \mathrm{~cm}$ kalınlığındaki ahşap ya da kütükler köşelerde birbirleri üzerine kurt boğazı geçme ile bindirilmektedir ${ }^{49}$. Kütük yığma sistemler genellikle tek katlı ek ve servis yapılarında ve dağlık alanlarda ya da iki katlı yapılarda zemin katlarının inşasında kullanılmaktadır ${ }^{50}$ (G. 4). İşlenmiş ahşap yığma sistemler ise genellikle yarı gömülü taş yığma sistemle inşa edilmiş zemin katların üzerinde bulunmaktadır ${ }^{51}$ (G. 3). Bu teknik iç ve dış duvarların eş zamanlı inşa edilmek zorunluluğu ve zorluğu

43 Metin Sözen ve Cengiz Eruzun, Anadolu'da Ev ve İnsan (Y.Y: Emlak Bankası Yayınları, 1992), 122; Özgüner, Köyde Mimari: Doğu Karadeniz, 22; Sümerkan, "Gelenekselden Betonarmeye Trabzon Kırsal Mimarl1ğı”, 83; Sümerkan, Biçimlendiren Etkenler Açısından Doğu Karadeniz Kırsal Kesiminde Geleneksel Evlerin Yapı Özellikleri, 75.

44 Özgüner, Köyde Mimari: Doğu Karadeniz, 23.

45 Özgüner, Köyde Mimari: Doğu Karadeniz, 23.

46 Sümerkan, "Gelenekselden Betonarmeye Trabzon Kırsal Mimarlığı", 83.

47 Özgüner, Köyde Mimari: Doğu Karadeniz, 26.

48 Sözen ve Eruzun, Anadolu'da Ev ve İnsan, 122; Sümerkan, Biçimlendiren Etkenler Açısından Doğu Karadeniz Kırsal Kesiminde Geleneksel Evlerin Yapı Özellikleri, 68.

49 Özgüner, Köyde Mimari: Doğu Karadeniz, 32.

50 Cengiz Eruzun, "Significance of Wood in Formation of Traditional Turkish Architecture and Eastern Black Sea Example", Proceedings of the 15th International Symposium of the IIWC'de sunulan bildiri, İstanbul, 20 Eylül, 2006, 11. Bk. http://iiwc.icomos.org/assets/2006-eruzun2.pdf, erişim 28 Haziran 2021; Sözen ve Eruzun, Anadolu'da Ev ve Insan, 110.

51 Eruzun, "Significance of Wood in Formation of Traditional Turkish Architecture and Eastern Black Sea Example", 12. 
sebebiyle daha çok bir-iki odalı köy evlerinde ve basit planlı depo yapılarında kullan1lmaktadir ${ }^{52}$.

Sözen ve Eruzun'a göre, ahşap yığma sistemle inşa edilmiş yapılarda, alt katlar kütük yığma, üst katlar ise işlenmiş ahşap yığma sistemdir ${ }^{53}$ (G. 4, G. 6). Evin büyüklüğüne göre, 30-60 cm arasında değişen köşeleri boğaz geçmeli sistemle bağlanmış kütükler kullanılmaktadır. Üst katların inşası sırasında, kütük yığma tekniğiyle inşa edilen duvarın üzerine, ilk olarak taban ağaçları ve döşeme ana kirişleri yerleştirilmekte, daha sonra üzerlerine döşeme kirişleri konulmaktadır. Dış duvarların inşası sırasında, 4-6 cm kalınlığındaki tahtalar üzerine 15-20 cm mesafede kertikler açılarak, köşelerde boğaz geçme tekniğiyle birleştirilir (G. 7). Kullanılan ahşabın boyut ve niteliğine bağlı olarak, köşelerdeki boğaz geçmeleri, "kertme boğaz", "kurt boğazı", "çalma boğaz", "kara boğaz" olarak adlandırılmakta, kullanılan ahşap elemanlar, geçme noktalarından, 15-30 cm uzunluğunda çıkıntı yaparak birbiri üzerine oturtulmaktadır ${ }^{54}$. "Kara boğaz” geçme sistemi, çoğunlukla kütük yığma sistemlerde kullanılmaktadır ${ }^{55}$. Çamlıhemşinli yapı ustası Ali Yağc1 "kurt boğazı sistemle bağlanan ahşap elemanların birbirinden ayrılmasının mümkün olmadığını, bu nedenle depreme ya da darbelere karşı çok dirençli ve uzun ömürlü olduğunu" 56 söylemektedir.

Ahşap yığma sistemde, dış ve iç bölme duvarlarının aynı anda yapılmasının zorunluluğu ile açıklıklar oluşturulurken yaşanan güçlüklerden dolayı, bölmeler, pencere boşlukları ve iç duvarlarda kapı boşlukları açılırken "dolma” sistem kullanılmak$\operatorname{tad}{ }^{57}$. Bu bakımdan, birçok yapıda, ahşap yı̆̆ma sistemin yığma ve karkas sistem karışımı bir yapım tekniği olduğu belirtilebilir ${ }^{58}$.

52 Başkan, "Geleneksel Doğu Karadeniz Evleri", 45.

53 Sözen ve Eruzun, Anadolu'da Ev ve Insan, 110.

54 Özgüner, Köyde Mimari: Doğu Karadeniz, 32; Koray Güler ve Ayșe Ceren Bilge, "Doğu Karadeniz Ahşap Karkas Yapı Geleneği ve Koruma Sorunları”, Ahşap Yapılarda Koruma ve Onarım Sempozyumu 2 Bildiri Kitabı (İstanbul: İstanbul Büyükşehir Belediyesi Yayınları, 2013), 184.

55 Özgüner, Köyde Mimari: Doğu Karadeniz, 33.

56 Kaynak Kişi: Ali Yağcı, Bk. Sisler Kovulunca: Eski Evler, Eski Ustalar, Doğu Karadeniz, Belgesel film.

57 Özgüner, Köyde Mimari: Doğu Karadeniz, 34; Sümerkan, Biçimlendiren Etkenler Açısından Doğu Karadeniz Kırsal Kesiminde Geleneksel Evlerin Yapı Özellikleri, 69.

58 Sözen ve Eruzun, Anadolu'da Ev ve Insan, 110. 

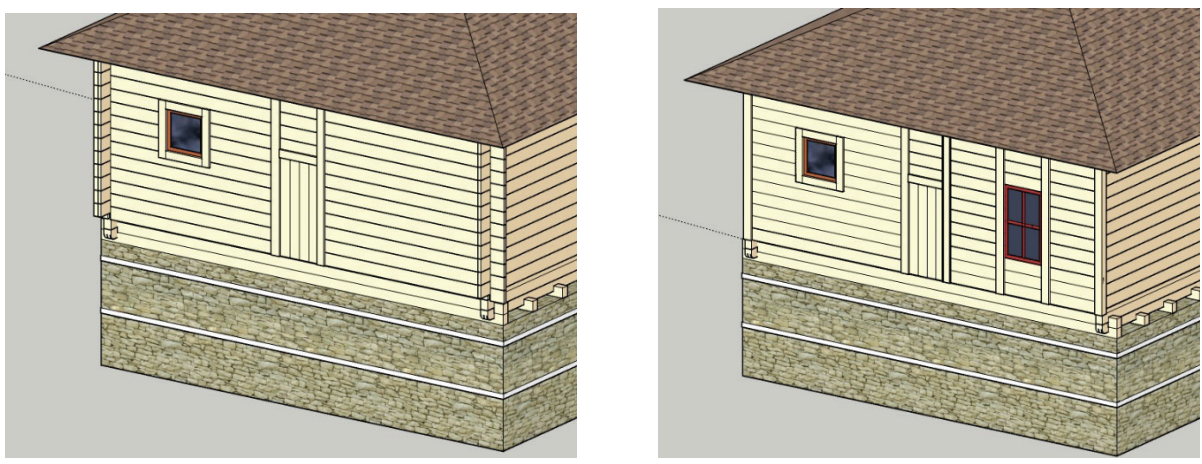

G. 3: (Sol) Yı̆̆ma taş duvar üstünde ahşap yığma sistemle yapılmış ev. (Sağ) Yığma taş duvar üstünde ahşap çatma sistemle yapılmış ev (Çizimler: Özlem Karakul)

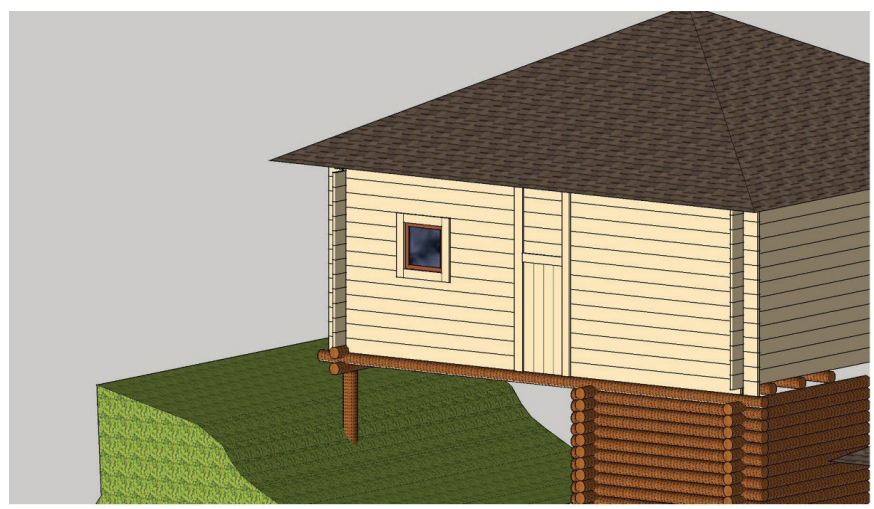

G. 4: Kütük yığma sistem üstünde ahşap yığma sistemle yapılmış ev (Çizim: Özlem Karakul)

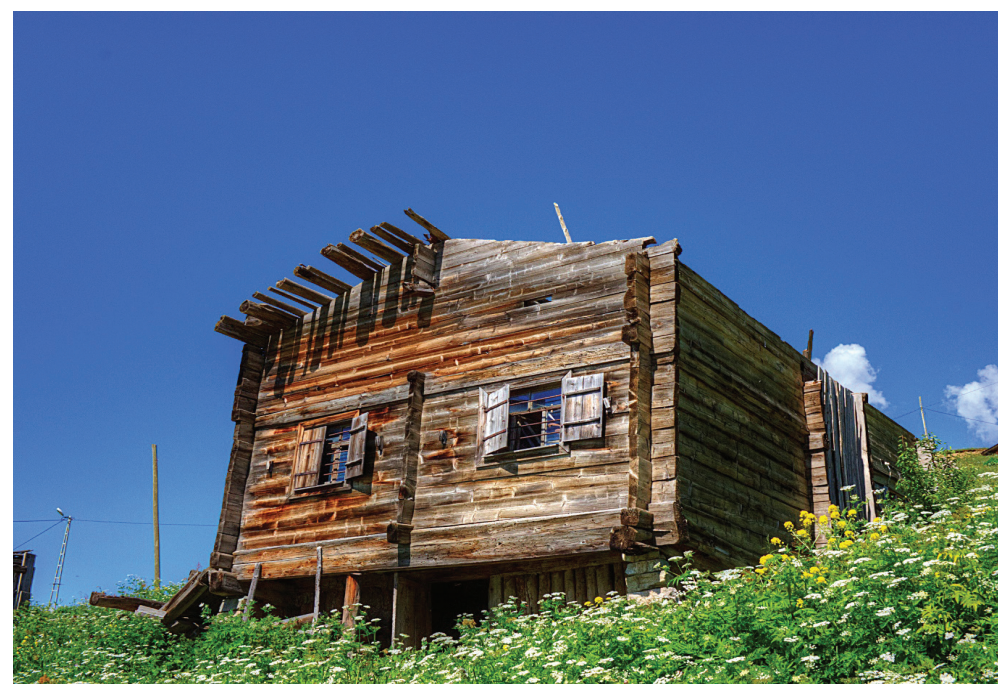

G. 5: Ahşap yığma sistemle yapılmış ev, Rize (Kaynak: Yüksel Aslan Arşivi) 


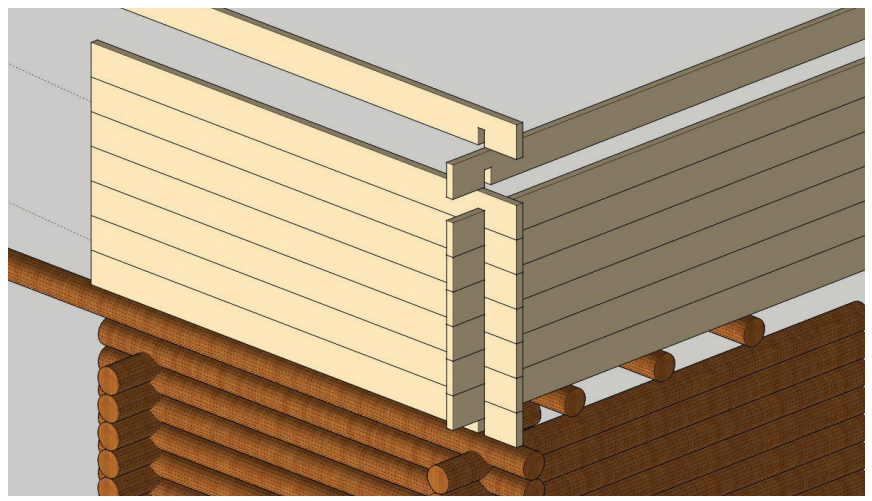

G. 6: Kütük yığma sistem üstü ahşap yığma sistem köşe birleşim detayı (Çizim: Özlem Karakul)

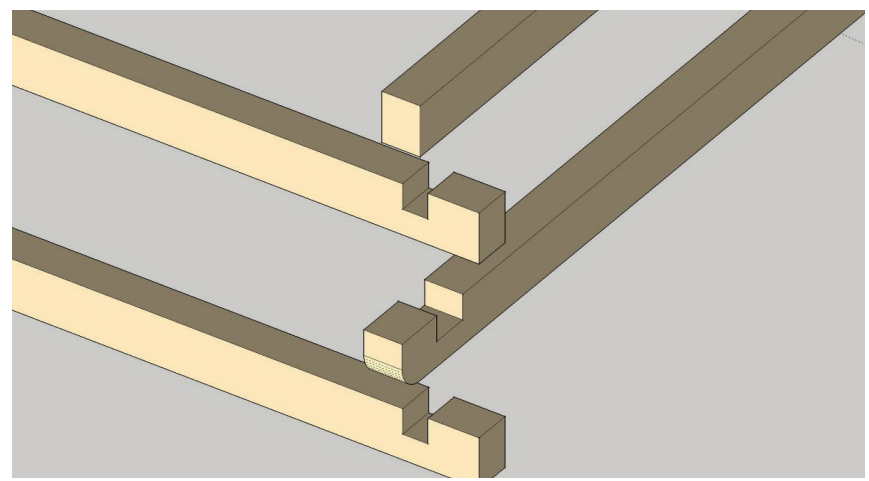

G. 7: Yığma taş duvar üstünde ahşap yığma sistem kirişlerin köşe birleşim detay1 (Çizim: Özlem Karakul)

\section{Ahşap Çatma Tekniği}

Yerel dilde Çatma olarak tanımlanan tekniğin, prensipte benzerlik gösterdiği karkas yapı tekniğinden farkı, cepheyi oluşturan dikme aralıklarının darlığıdır (G. 8). Çatma tekniğinde, cephede düşey ve yatay ya da çapraz ahşap elemanlarla kare ya da üçgen biçiminde boşlukları olan bir doku oluşturulur ve bu boşluklar taşla doldurulur. Yatay bağlantı yapıldığında ortaya çıkan kare şekilli boşluklardan oluşan desene "göz dolması" adı verilmektedir. Çapraz bağlantıların ortaya çıkardığı üçgen şekilli boşluklardan oluşan desene ise "muskalı" denilmektedir"

Çatma tekniğinde, taşıyıcı elemanlar, yapının yükünü temel duvarlarına ileten düşey ahşap elemanlardır. Sözen ve Eruzun'a göre, genellikle $50 \mathrm{~cm}$ kalınlığında moloz taşla yapılan temel duvarları yükseltilerek bodrum kat elde edilmiştir. ${ }^{60}$ Karkas yapı 
strüktürü kurulurken önce $15 \times 15 \mathrm{~cm}$ kesitli taban ağaçları yerleştirilir, köşeler "boğaz geçme" ya da "kurt boğazı" olarak adlandırılan yarım geçmeyle birleştirilir. İkinci aşamada, taban ve kirişlerin üzerine geçme bir detayla düşey taşıyıcılar konulur.

Özgüner'e göre çatma sistemde, 5x10 cm kesitindeki dikmeler, $15-25 \mathrm{~cm}$ ara ile çepeçevre taban kirişi üzerine oturtulmaktadır. Bu dikmeler, sonradan yatay ya da çapraz parçalarla birbirine bağlanmaktadır. Köşe dikmeleri ve bölme yerlerindeki dikmeler ise, bağlantı ve geçmelerde kolaylık sağlamak için kare kesitlidir ${ }^{61}$.

Genellikle eş anlamlı kullanılan karkas ve çatma sistemi, Doğu Karadeniz Bölgesi'nde, yapım sistemlerindeki belirgin bir farklılı̆ğ işaret etmektedir. Ahşap karkas sistemde, dikmeler $80 \mathrm{~cm}$ aralıklarla taban kirişleri üzerine oturtulmakta, köşelerde çapraz destekler kullanılmaktadır ${ }^{62}$. Çatma sistemde sık ve boyutları küçük olan dikmelerin, karkas sistemde ara mesafeleri ve boyutları artmaktadır ${ }^{63}$. Çatma sistemde olduğu gibi, duvarların iç yüzeyi bağdadi veya ahşap kaplama, dış yüzleri, sıvalı, sıvasız dolgu ya da ahşap kaplama şeklindedir ${ }^{64}$.

Ahşap çatma sistemi, yapının kısa sürede çatısının tamamlanarak korunmasını sağladığı için çoğunlukla tercih edilmektedir. Özgüner'e göre, köylüler, çatısı inşa edilmiş bir evin, zamanla iç bölmelerini ve mimari elemanlarını tamamlamaktadırlar. ${ }^{65} \mathrm{Bu}$ yapım tekniği sırasında, "kara boğaz" veya "kurt boğazl” geçme teknikleri ${ }^{66}$ kullanılarak, ahşap yapı elemanları birbirlerine bağlanmış ve yapının depreme karşı direnci artırılmaktadır. Karadenizli yapı ustaları 104 yaşındaki Taştan Temur ile 60 yaşındaki Ali Yağcı, "kara boğaz ve kurt boğazı tekniklerinin çivi kullanılmadan yapılan geçme teknikleri olduğunu, depreme karşı dayanımı artırması nedeniyle, uzun yıllardır bu inşa tekniklerinin kullanıldığını" ${ }^{97}$ vurgulamaktadır.

61 Özgüner, Köyde Mimari: Doğu Karadeniz, 26.

62 Özgüner, Köyde Mimari: Doğu Karadeniz, 31.

63 Özgüner, Köyde Mimari: Doğu Karadeniz, 31.

64 Özgüner, Köyde Mimari: Doğu Karadeniz, 31.

65 Özgüner, Köyde Mimari: Doğu Karadeniz, 31.

66 Kaynak Kişiler: Taştan Temur, Ali Yağcı, Bk. Sisler Kovulunca: Eski Evler, Eski Ustalar, Doğu Karadeniz, Belgesel film.

67 Kaynak Kişiler: Taştan Temur, Ali Yağcı, Bk. Sisler Kovulunca: Eski Evler, Eski Ustalar, Doğu Karadeniz, Belgesel film. 


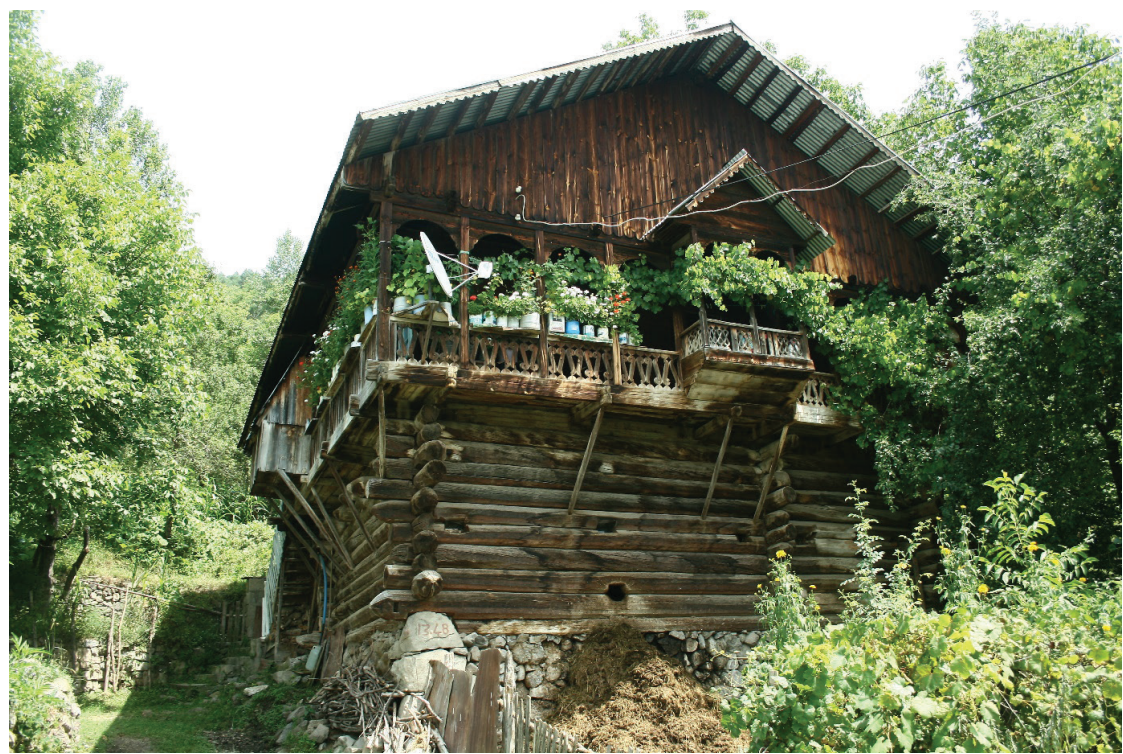

G. 8: Yığma taş duvar üstü ahşap yığma tekniği ve üzerinde ahşap çatma tekniği, Artvin, Şavşat (Kaynak: Selim İhtiyar Arşivi)

Çatma yapılarda, dolgu tekniğine göre cepheler üç şekilde kurulmaktadır:

\section{a. Ahşap Dolma}

Yığma tekniğin bir türevi olan dolma tekniğinde yapılar, hacimlerin köşelerine yerleştirilen dikmelerin arasına konulan tahtaların üst üste geçirilmesiyle inşa edilmekte$\operatorname{dir}^{68}$ (G. 9). Taşıyıcı dikmeler arasında, dolgu malzemesi olarak ahşabın kullanıldığ bu sistemde, 2,5-6 cm kalınlığında ve 25-40 cm genişliğinde, genellikle, sert ağaç ve çıralı çam ahşaplar, yatay biçimde üst üste dizilmektedir ${ }^{69}$. Tahtaların ek yapılabilmesi için kanal açılmış dikmeler, köşelerde ve ek yapılması gerekli yerlerde kullanılmakta-

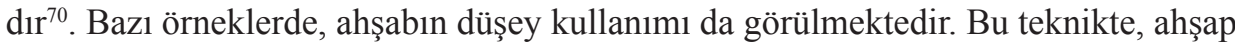
elemanlar, birbirlerine ahşap çivilerle sabitlenmektedirler ${ }^{71}$. Yapı ustaları, pencere ve kapı boşluklarının iki kenarına ve planda ara bölmelerin olduğu bölümlere ahşap dikmeler yerleştirerek, tavan ve taban kirişi arasındaki boşluğu ahşap levha ve çivilerle tamamlamaktadırlar ${ }^{72}$.

68 Koray Güler, Doğu Karadeniz Kırsal Mimarisi Örneklerinden Rize-Fındıklı Aydınoğlu Evi Restorasyon Projesi, (Yüksek Lisans Tezi, İstanbul Teknik Üniversitesi, 2012), 43.

69 Sümerkan, Biçimlendiren Etkenler Açısından Doğu Karadeniz Kırsal Kesiminde Geleneksel Evlerin Yapı Özellikleri, 70; Sözen ve Eruzun, Anadolu'da Ev ve İnsan, 123.

70 Sümerkan, Biçimlendiren Etkenler Açısından Doğu Karadeniz Kırsal Kesiminde Geleneksel Evlerin Yapı Özellikleri, 70 .

71 Güler ve Bilge, "Doğu Karadeniz Ahşap Karkas Yapı Geleneği ve Koruma Sorunları”, 185.

72 Güler ve Bilge, "Doğu Karadeniz Ahşap Karkas Yapı Geleneği ve Koruma Sorunları”, 185. 


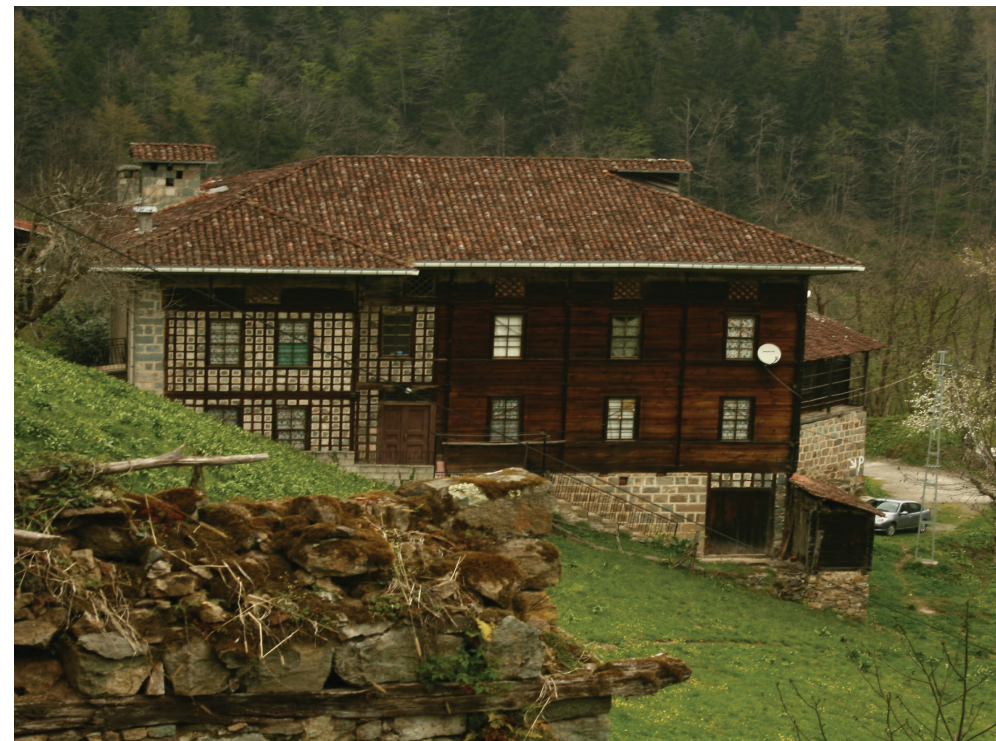

G. 9: Kesme taş duvar üstü ahşap dolma tekniği ve göz dolma tekniği, Rize (Kaynak: Selim İhtiyar Arşivi)

\section{b. Göz Dolma}

Göz dolma tekniğinde, dikmeler arasındaki 15-30 cm'lik boşluklar, 15-22 cm aralıklı yatay ahşap elemanlarla bölünerek kare ya da dikdörtgen kutucuklar oluşturulmaktadır $^{73}$ (G. 10, G. 11, G. 12, G. 13). Oluşan boşlukların göz göz olması sebebiyle bu sisteme göz dolması denilmektedir. Göz dolma tekniğinde kullanılan ahşap dikmelerin kesitleri, ahşap çatma sistemdekilere göre daha küçük, aralarındaki mesafe ise daha azdır ${ }^{74}$. Göz dolma tekniğinde, boşluklara genellikle tek blok kesme taş ve toprak harç karışımı doldurulup üzeri kireçle sıvanmaktadır ${ }^{75}$. Dolgu ile ahşap elemanların arasındaki boşluklar killi harçla doldurulmaktadır ${ }^{76}$ (G. 14). Göz dolma tekniğini kullanarak bölgede 160 tane ev inşa eden Kasım Tavukçuoğlu Usta "tahta yığma teknikle yapılan duvarlardan eve soğuk girdiğini, daha kalın olan göz dolma duvarlardan ise soğuğun giremediğini"'77 vurgulayarak bu tekniği tercih etmesinin sebebini açıklamaktadır.

73 Sözen ve Eruzun, Anadolu'da Ev ve İnsan, 123; Sümerkan, Biçimlendiren Etkenler Açısından Doğu Karadeniz Kırsal Kesiminde Geleneksel Evlerin Yapı Özellikleri, 71; Özgüner, Köyde Mimari: Doğu Karadeniz, 28.

74 Sümerkan, Biçimlendiren Etkenler Açısından Doğu Karadeniz Kırsal Kesiminde Geleneksel Evlerin Yapı Özellikleri, 71 .

75 Güler, Doğu Karadeniz Kırsal Mimarisi Örneklerinden Rize-Fındıklı Aydınoğlu Evi Restorasyon Projesi, 44.

76 Sümerkan, Biçimlendiren Etkenler Açısından Doğu Karadeniz Kırsal Kesiminde Geleneksel Evlerin Yapı Özellikleri, 70 .

77 Kaynak Kişi: Kasım Tavukçuoğlu, bk. Sisler Kovulunca: Eski Evler, Eski Ustalar, Doğu Karadeniz, Belgesel film. 
Göz dolma tekniğinde, moloz taş duvar üzerine kurt boğazı tekniğiyle birleştirilmiş $15 \times 15 \mathrm{~cm}$ kesitli taban kirişinin üzerine $15-25 \mathrm{~cm}$ aralıklarla, $8 \times 8 \mathrm{~cm}$ ya da $10 \times 10 \mathrm{~cm}$ boyutlarındaki ahşap dikmelerin sabitlenerek, ara boşluklar 3-5 cm kalınlığındaki yatay ahşap parçalarla eşit aralıklarla bölünmekte, $20-30 \mathrm{~cm}$ aralıklarla, dikmelere açılan boşluklara geçmeli olarak oturtulmaktadır ${ }^{78}$. Tek bir taş ya da bir yüzeyi çok düzgün dere taşları kırılarak, küçük taşlarla doldurularak yapılan duvarların iç yüzeyi çıtalarla kaplanarak sivanmakta (bağdadi) veya tahtalarla kaplanmaktadır ${ }^{79}$. Bölgede eskiden tamamen geçme yapım tekniği ile inşa edilen konutlarda sonraları çivi bağlama ve geçme bağlantılarının bir arada kullanımı devam etmiştir ${ }^{80}$.
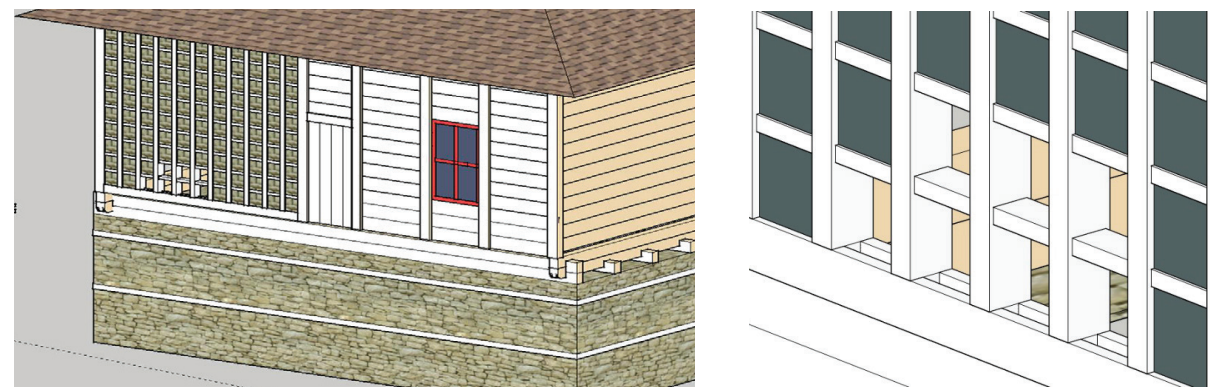

G. 10: Ahşap karkas sistemde göz dolma tekniği (Çizim: Özlem Karakul)

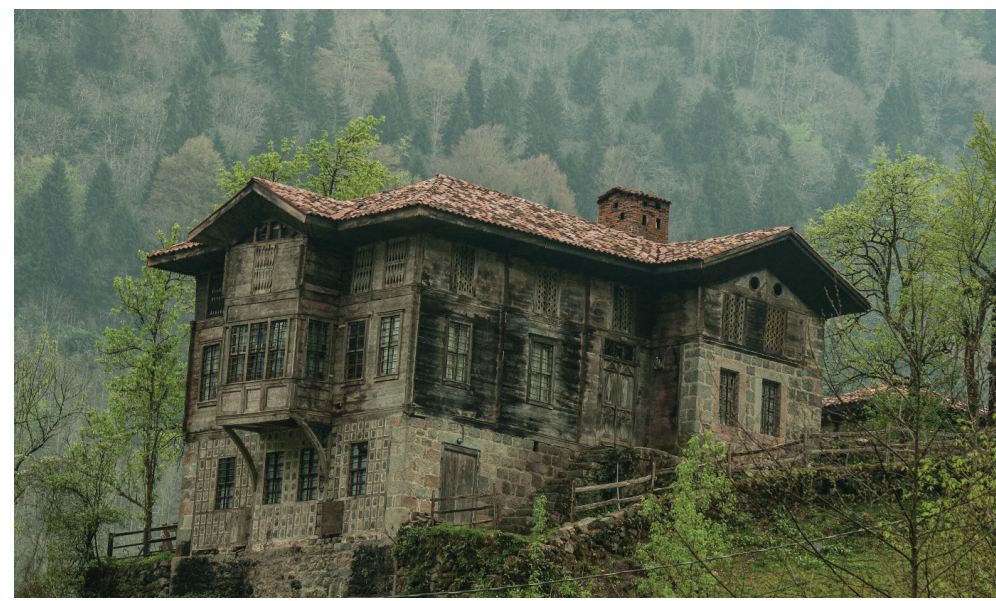

G. 11: Yığma taş duvar üstünde ahşap çatma sistemde göz dolma tekniği ve ahşap dolma tekniği, Rize (Kaynak: Selim İhtiyar Arşivi)

78 Güler ve Bilge, "Doğu Karadeniz Ahşap Karkas Yapı Geleneği ve Koruma Sorunları", 186.

79 Özgüner, Köyde Mimari: Doğu Karadeniz, 30; Sümerkan, Biçimlendiren Etkenler Açısından Doğu Karadeniz Kırsal Kesiminde Geleneksel Evlerin Yapı Özellikleri, 71.

80 Özgüner, Köyde Mimari: Doğu Karadeniz, 35. 


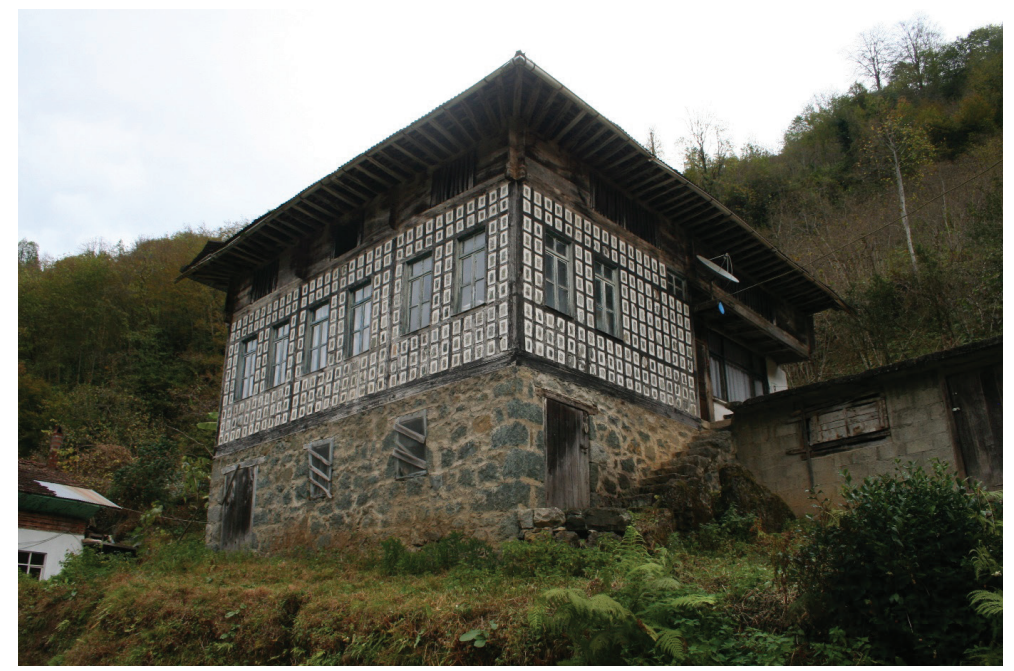

G. 12: Ahşap çatma sistemde göz dolma tekniği (Kaynak: Kültür ve Turizm Bakanlığı Arşivi) https://www.ktb.gov.tr/yazdir?8E12B514BE83CADCEAF90FCBE3F42130
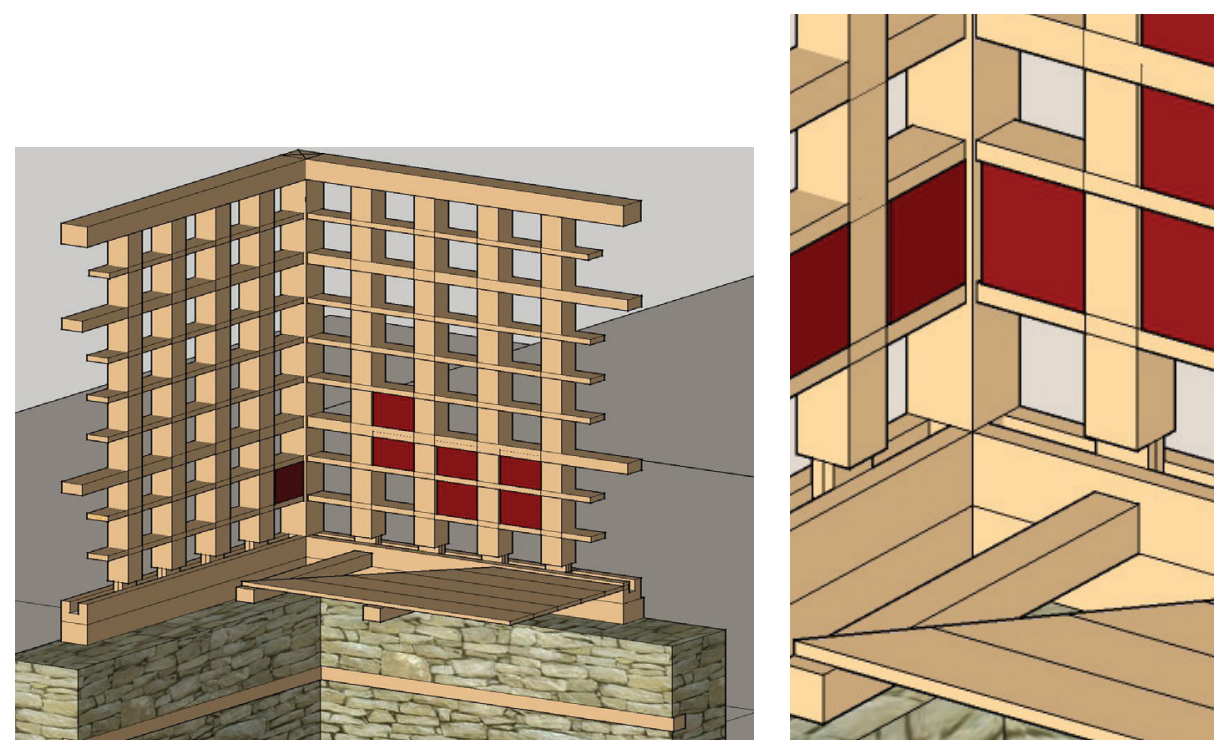

G. 13: Ahşap çatma sistemde göz dolma tekniği (Çizim: Özlem Karakul) 

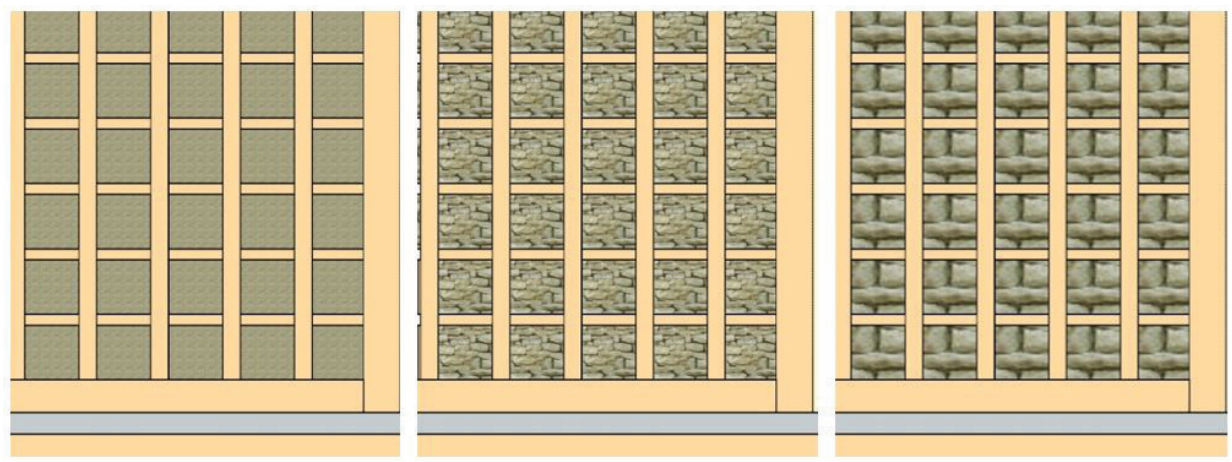

G. 14: Göz dolma tekniğinde farklı boyutlarda taş ve killi harçla yapılan dolgular (Çizim: Özlem Karakul)

\section{c. Muskalı Dolma}

Muska tekniğinde de göz dolma tekniğinde olduğu gibi, ana ve ara taşıyıcılar aynı aralıklarla kurulmakta, yalnız küçük kesitli ahşap dikmelerin aralıkları daha büyük $(25-35 \mathrm{~cm})$ tutulmaktadır (G. 15). Bu dikmelerin arasına ise 45 derece eğilmiş ahşap elemanlar yerleştirilmektedir ${ }^{81}$. Oluşan üçgen boşlukların muskaya benzemesi sebebiyle halk arasinda bu sisteme Muskall ya da Muskall Dolma denmektedir ${ }^{82}$. Bu teknikle yapılan evler, bölgede, Muskalı ev olarak adlandırılmaktadır ${ }^{83}$. Boşluklara uygun tek parça taş bulunamadığından birkaçı bir arada olmak üzere küçük taşlar kireç harçla yerlerine yerleştirilmektedir (G. 16). Bölgede 487 adet ev inşa eden, 78 ve 68 yaşındaki Müslüm ve İsmail Dilaver Kardeşler "eğik tahtaların dikmelere birleştirilmesi için genellikle metal çiviler kullanıldığını" ${ }^{\prime 4}$ söylemektedirler. Sözen ve Eruzun, muskalı dolma sisteminde geçme yerine metal bağlantı elemanlarının kullanılmasının bu tekniğin daha sonra ortaya çıktığının bir göstergesi olabileceğini belirtmektedir. ${ }^{85}$ Güler ve Bilge, üçgen boşlukların dış cephede taş parçalarla doldurulduğunu, iç yüzeyde ise kil ya da kireç harcı ile derzlenerek tamamlandığını ifade etmektedir. ${ }^{86}$

81 Sümerkan, Biçimlendiren Etkenler Açısından Doğu Karadeniz Kırsal Kesiminde Geleneksel Evlerin Yapı Özellikleri, 73 .

82 Özgüner, Köyde Mimari: Doğu Karadeniz, 28; Sözen ve Eruzun, Anadolu'da Ev ve İnsan, 124.

83 Kaynak Kişiler: Müslüm ve İsmail Dilaver, Sisler Kovulunca: Eski Evler, Eski Ustalar, Doğu Karadeniz, Belgesel film.

84 Kaynak Kişiler: Müslüm ve İsmail Dilaver, Sisler Kovulunca: Eski Evler, Eski Ustalar, Doğu Karadeniz, Belgesel film.

85 Sözen ve Eruzun, Anadolu'da Ev ve Insan, 124.

86 Güler ve Bilge, "Doğu Karadeniz Ahşap Karkas Yapı Geleneği ve Koruma Sorunları”, 188. 

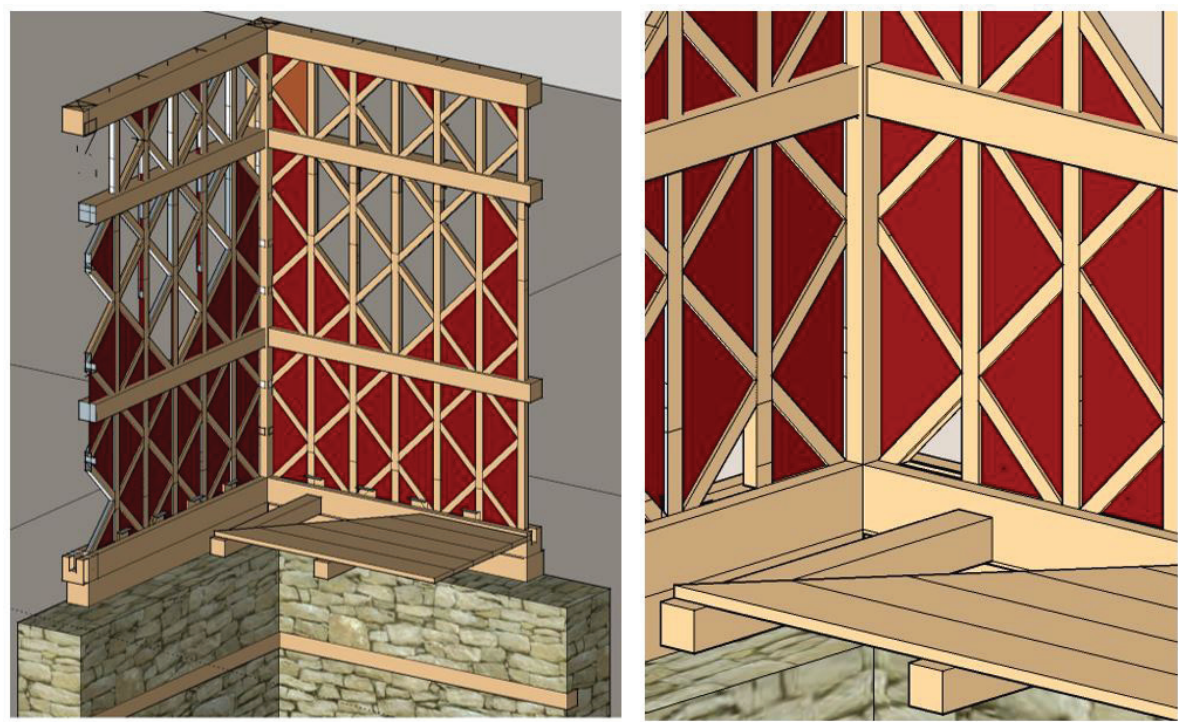

G. 15: Ahşap karkas sistemde muska tekniği (Çizim: Özlem Karakul)
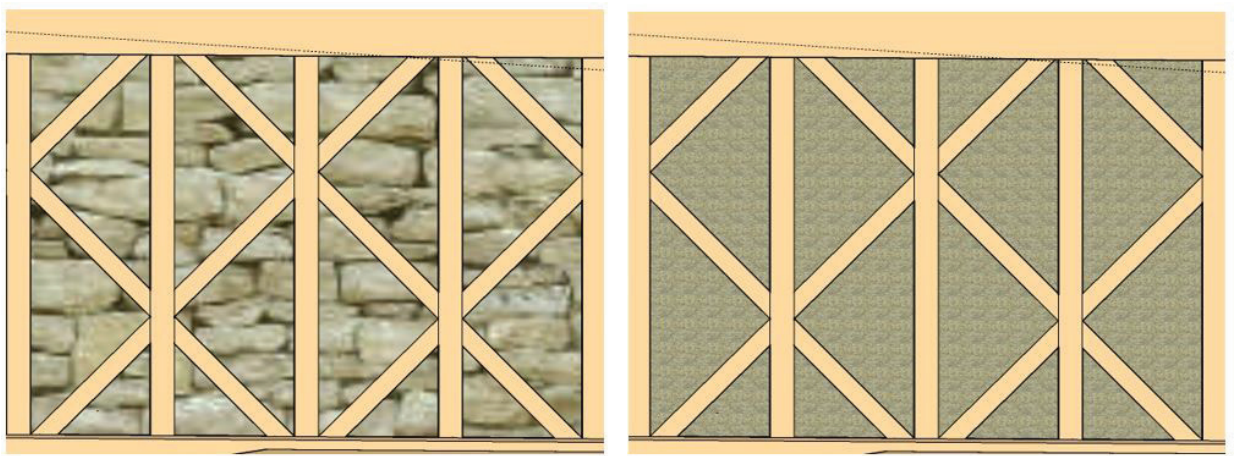

G. 16: Muska tekniğinde taş ve kireç harcıyla yapılan dolgular (Çizim: Özlem Karakul)

\section{Çakatura}

Anadolu'da pek çok yerde bağdadi olarak tanımlanan dikmeler arası boşluk yüzeyinin çıtalarla kaplanıp üzerinin sıvanması ile oluşturulan tekniğe bu bölgede Çakatura adı verilmektedir. Bağdadi tekniğinin çoğunlukla Artvin yöresindeki adı olarak anlatılan Çakatura tekniği, Doğu Karadeniz Bölgesi'nde ahşap çatma sistemle yapılmış evlerin dış yüzeyinde bağdadi kullanılma tekniğgi olarak açıklanmaktadır ${ }^{87}$. Çakatura tekniği, ahşap çatma sistemde kullanılan dikmelerin arasına sık aralıklarla çıtalar çakılarak oluşturulan ızgara aralarının çamurdan taşa kadar çeşitli malzemelerle doldu-

87 Başkan, “Geleneksel Doğu Karadeniz Evleri”, 45; Özgüner, Köyde Mimari: Doğu Karadeniz, 26. 
rularak üzerinin sıvanmasıyla oluşmaktadır ${ }^{88}$. Sürmeneli yapı ustası 92 yaşındaki Ali Rıza Alioğlu'ya göre “muska ya da çakatura tekniği kullanılarak yapılan duvarların üzerine ince çıtalar çakılarak, sıva vurulması tekniği, muskalı ve bağdadi olarak" ${ }^{\prime 99}$ adlandırılmaktadır. 87 yaşındaki Ömer Keleşoğlu Usta ise "çakatura tekniğinde, ahşap dikmelerin arasının taş ve çamur karışımıyla doldurulduğunu" ${ }^{90}$ belirtmektedir. Ali Rıza Alioğlu Usta ise "çakatura tekniğinin, evlere 1sı ve ses izolasyonu sağladığını”, bu teknikte yapılan "evlerin nefes aldığını ve sağlıklı olduğunu" vurgulamaktadır".

\section{İç Bölme Duvarlar ve Döşemeler}

Doğu Karadeniz Bölgesi’nin geleneksel konutlarında, iç bölme duvarları 2-4 cm kalınlıkta ahşap elemanlar kullanılarak yapılmıştır ${ }^{92}$. Köşelerde ve bağlantı yerlerinde konulan, kanallar açılmış dikmelerin arasına, genellikle yatay, nadiren dikey ahşap elemanlar üst üste ya da yan yana dizilmiştir³.

Karadeniz evlerinde, bodrum kat döşemelerinde çoğunlukla taş, diğer kat döşemelerinde ahşap kullanılmıştır ${ }^{44}$. Döşemelerin inşası sırasında, dikdörtgen ya da dairesel kesitli ahşap kirişlerin üzerine, 1,5-2 cm kalınlığındaki ahşap plakalar kaplanmaktadır. Oda döşemeleri, taş yığma duvarlar üzerine konulan taban kirişlerinin üzerine, genellikle kısa yönde yerleştirilen zemin kat döşeme kirişlerinin bindirilmesiyle inşa edilmektedir ${ }^{95}$. Aşhane mekânlarının zemini çoğunlukla sıkıştırılmış topraktır ${ }^{96}$.

\subsection{3. Çatı}

Doğu Karadeniz Bölgesi'nin geleneksel konutlarının çatıları çoğunlukla ahşap taş1yıcılarla inşa edilmiş olup yağışların yoğunluğundan dolayı oldukça eğimlidir ${ }^{97}$. Çat1lardaki eğim, bol yağışı iklim koşullarının yanı sıra, ahşap konstrüksiyon sisteminin getirdiği bir sonuçtur. Çatı biçimleri, genellikle, semer denilen iki eğimli, üç omuz da

88 Başkan, "Geleneksel Doğu Karadeniz Evleri”, 45.

89 Kaynak Kişi: Ali Rıza Alioğlu, bk. Sisler Kovulunca: Eski Evler, Eski Ustalar, Doğu Karadeniz, belgesel film.

90 Kaynak Kişi: Ömer Keleşoğlu, bk. Sisler Kovulunca: Eski Evler, Eski Ustalar, Doğu Karadeniz, Belgesel film.

91 Kaynak Kişi: Ali Rıza Alioğlu, bk. Sisler Kovulunca: Eski Evler, Eski Ustalar, Doğu Karadeniz, Belgesel film.

92 Sümerkan, "Gelenekselden Betonarmeye Trabzon Kırsal Mimarlığı", 85; Sümerkan, Biçimlendiren Etkenler Açısından Doğu Karadeniz Kırsal Kesiminde Geleneksel Evlerin Yapı Özellikleri, 75.

93 Sümerkan, Biçimlendiren Etkenler Açısından Doğu Karadeniz Kırsal Kesiminde Geleneksel Evlerin Yapı Özellikleri, 75 .

94 Başkan, "Geleneksel Doğu Karadeniz Evleri”, 48.

95 Sümerkan, Biçimlendiren Etkenler Açısından Doğu Karadeniz Kırsal Kesiminde Geleneksel Evlerin Yapı Özellikleri, 75 .

96 Sümerkan, Biçimlendiren Etkenler Açısından Doğu Karadeniz Kırsal Kesiminde Geleneksel Evlerin Yapı Özellikleri, 75 .

97 Sümerkan, Biçimlendiren Etkenler Açısından Doğu Karadeniz Kırsal Kesiminde Geleneksel Evlerin Yapı Özellikleri, 76 . 
denilen üç yöne eğimli ve dört omuz denilen dört yöne eğimlidir ${ }^{98}$. Çatı yapımı duvarların üzerine genellikle dış yüzeye, yastık kirişlerinin yerleştirilmesiyle başlamaktadır 99 . Yastık kirişlerinin üzerine yerleştirilen tavan döşeme kirişleri üzerine "omuz ağacı" adı verilen mahya kirişini taşıyacak dikmeler konulur, ardından yapının dar kenarlarını birleştirecek biçimde makaslar oluşturularak mertekler oturtulmaktadı1 ${ }^{100}$. Kullanılacak kaplama malzemesine göre değişen mertek aralıkları, geçmişte hartama kullanıldığı dönemde $20 \mathrm{~cm}$ olarak ayarlanır ve saçağa paralel oluşturulurdu ${ }^{101}$. Kiremitle kaplanacak çatılarda eğim yönünde 30-50 cm arayla mertekler yerleştirilerek üzerine kiremit altı çıtaları konulur ve üzeri kaplanırd $1^{102}$.

Doğu Karadeniz evlerinde geleneksel çatı kaplama malzemesi çoğunlukla, bazı yörelerde Hartama ya da Artvin'in Şavşat ilçesi gibi bazı bölgelerde Bedevra ya da Pedavra denilen ahşap levhalardan oluşmaktadır ${ }^{103}$. Geleneksel teknikle inşa edilmiş evlerin çoğunluğu Hartamayla kaplanmıştır. 80-100 cm boyunda kesilmiş olan kütüklerin kesilmesiyle elde edilen Hartamalar, üst üste bindirilerek kaplanmakta ve rüzgâr etkisinden korunmak için üzerine sırayla taşlar konmaktadır ${ }^{104}$. Reçineli ağaçlardan lifler yönünde dilimlenerek elde edilen, kullanılan ağacın cinsine göre kalınlığ değişen hartamalar, köknar, ladin veya meşe ağacından yaklaşık bir santimetre kalınlığında, kestane ağacından ise iki santimetre kalınlıkta yapılmaktadır ${ }^{105}$. Derin Kökler belgeselinde görüşme yapılan Gümüşhane Kırgeriş Köyü’nden bir yapı ustası "hartamanın siyah çam, ladin ve kayın ağacından yapıldığını"106 belirtmektedir. Belgeselde görüşmelerin yapıldığı yapı ustaları "ladinden yapılan hartamanın en iyisi olduğunu" söyleyerek hartama yapacakları ağacı belirlemek için ağacın $15 \mathrm{~cm}$ yüksekliğindeki bir yerinden $4-5 \mathrm{~cm}$ derinlikte bir parçayı kopararak incelemekte ve eğer ağaç hartama yapımına uygunsa ağacı kesmektedirler. "Çapraz yarılan, burkulan ağaçtan hartama olamayacağını" söyleyen ustalara göre, "hartama yapılacak ağacın düzgün yarılması" gerekir. Bir kütükten yaklaşık 300 adet hartama çıktığını söyleyen ustalar 100 hartamayı ise bir bağ olarak tanımlamaktadırlar. Kütüğü yardıktan sonra dörde bölen ustalar parçaların her birine dörder adını vermektedir. Dörderlerin her

98 Özgüner, Köyde Mimari: Doğu Karadeniz, 36.

99 Sümerkan, Biçimlendiren Etkenler Açısından Doğu Karadeniz Kırsal Kesiminde Geleneksel Evlerin Yapı Özellikleri, 77 .

100 Sümerkan, Biçimlendiren Etkenler Açısından Doğu Karadeniz Kırsal Kesiminde Geleneksel Evlerin Yapı Özellikleri, 77.

101 Sümerkan, Biçimlendiren Etkenler Açısından Doğu Karadeniz Kırsal Kesiminde Geleneksel Evlerin Yapı Özellikleri, 77. Özgüner, Köyde Mimari: Doğu Karadeniz, 38.

102 Sözen ve Eruzun, Anadolu'da Ev ve İnsan, 129.

103 Özgüner, Köyde Mimari: Doğu Karadeniz, 24; Oğuz, Türkiye Halkının Kültür Kökenleri-3| İnşa, Isitma ve Aydınlatma Teknikleri, 338; Sümerkan, Biçimlendiren Etkenler Açısından Doğu Karadeniz Kırsal Kesiminde Geleneksel Evlerin Yapı Özellikleri, 64.

104 Sözen ve Eruzun, Anadolu'da Ev ve Insan, 110.

105 Özgüner, Köyde Mimari: Doğu Karadeniz, 24.

106 Muhammed Salih Şimşek, Derin Kökler-81. bölüm, belgesel film, TRT, 2005. https://www.youtube.com/ watch?v=0C63Qx_mw9k, erişim 28 Haziran 2021). Belgeselde ustanın adı belirtilmemiştir. 
birinin ön tarafı baltayla yontularak, hartama yapılacak kısımlar ayrılmaktadır. Dış kabuğu atıldıktan sonra, ağacın "yarılış biçimine" göre, düzgün ayrılmıyorsa $1 \mathrm{~cm}$, düzgün ayrılıyorsa yarım cm kalınlığında hartamalar, baltayla yontularak oluşturulmaktadır. Hartamaların çatıya kaplanması sırasında önce iki hartama üst üste bindirilmekte, daha sonra aralarına bir hartama daha konularak su damlaması önlenmektedir. Hartama kullanılan çatılarda "yağmurun çok hoş bir ses çıkardığını" anlatan yapı ustaları, "bu sesin insanı rahatlattığını, huzur verdiğini ve rahat bir uyku sağladığını"107 belirtmektedirler. Alaturka kiremidin yaygınlaşmasıyla birlikte, çatılarda hartama kullanımından vazgeçilmiştir.

\section{Değerlendirme}

Doğu Karadeniz Bölgesi’nin geleneksel konutları, geleneksel yapı ustalarının yağışı iklim ve aşırı eğimli yer koşullarıyla mücadele ederek, kullanıcıların ekonomik ve kültürel yapısına uyumlu bir biçimde, yüzlerce yıldır sürdürdükleri yapı geleneğinin ürünleridir. Çoğunlukla ahşap ve taş kullanılarak inşa edilen Doğu Karadeniz'in geleneksel konutları, oldukça zengin bir ahşap yapım teknikleri çeşitliliği sergilemektedir. Yapı ustalarının ahşabı konutlarda kullanım biçimleri yığma ve çatma olarak iki türlüdür. Yığma ahşap yapılarda, yığma taş taban duvarlarının üzerine, yapı ustaları kurt boğazı, kara boğaz gibi farklı köşe birleşim detayları ve geçme teknikleri kullanarak ahşapları üst üste dizmektedir. Çatma yapılarda ise inşa süreci sırasıyla, yığma taş tabanların inşası, ahşap dikmelerin yerleştirilmesi, dikmelerin aralarındaki bağlayıcı ahşap elemanların üçgen ya da dikdörtgen boşluklar oluşturacak şekilde, muska ya da göz dolma tekniğiyle yerleştirilmesi ve boşlukların, taş, çamur, kireç harcıyla doldurulmasıyla oluşturulmaktadır. Çakatura tekniğinde ise ustalar, çatma tekniğiyle dikilen ahşap dikmelerin ön ve arka yüzeylerine çıtalar çakarak içlerini çamur taş karışımıyla doldurduktan sonra üzerini sıvamaktadır.

\section{Sonuç}

Bu çalışmada, Doğu Karadeniz Bölgesi'nin geleneksel konutlarını, mimari özellikleri ve yapı ustalarının kullandığı bilgi, beceri ve teknikleri açısından inceleyen bütüncül bir değerlendirme yöntemi ortaya konulmuştur. Yap1 kültürünün somut olmayan değerleri ağırlıklı olarak belgesel araştırması sırasında elde edilen yapı ustalarıyla yapılan görüşme verileri incelenerek tespit edilmiştir. Literatür araştırması ve belgesel araştırmasıyla elde edilen yapı kültürünün somut ve somut olmayan değerleri, hazırlanan yap1 ve uygulama detaylarının üç boyutlu çizimleri üzerinde gösterilerek çalışmanın özgün yaklaşımı ve önceki çalışmalardan farkını da ortaya koyan bütüncül bir belgeleme yöntemi kullanılmıştır. Bütüncül belgeleme yöntemiyle elde edilen veriler, Doğu Karadeniz Bölgesi konutlarının korunmasına odaklanmış geleneksel 
konutların restorasyonu konusunda çalışan uzmanların ve bu konularda eğitim veren kurumların da kullanabileceği geleneksel yapım tekniklerine ilişkin bilgileri ortaya koyması açısından koruma alanına katkıda bulunmaktadır.

Yapı ustalarından elde edilen bilgiler, yapı kültürünün mimari özelliklerini oluşturan somut olmayan değerlerinin anlaşılması açısından önem taşımaktadır. Bu bağlamda, işitsel ve görsel arşivler, geleneksel yapı üretim sürecinin içinde ustaların çalışmalarının sözlü ve görsel kayıtlarının araştırılması için önemli bir kaynak olarak değerlendirilmelidir. Geleneksel zanaatlar hakkında görsel işitsel arşivlerde bulunan belge ve materyaller, görüntü ve ses kayıtları ile belgesel filmler, zanaatın uygulanma sürecini anlamaya ve belgelemeye yönelik kullanılmalıdır. Bu bağlamda, TRT Arşiv Dairesi Başkanlığı Belgesel Arşivi, farklı geleneksel zanaat uygulayıcılarının saptanması, zanaatın öğrenilmesi ve belgelenmesi açısından kullanılabilecek kapsamlı bir arşive sahiptir. Çalışma kapsamında, yapı kültürünün somut olmayan değerlerinin incelenmesi üzerine TRT Belgesel Arşivi'nde yapılan araştırma kapsamında, 19682009 yılları arasında yapılmış belgesel filmler taranarak bunlar arasında Doğu Karadeniz geleneksel mimarisi ve yapı ustalarıyla ilgili olanlar saptanmıştır. Ayrıca, Süha Arın tarafından 1986 yılında yapılan Doğu Karadeniz geleneksel evleri ve ustalarını konu alan Sisler Kovulunca belgeseli de yapı kültürünün somut olmayan değerlerinin incelenmesi için önemli bir kaynak olarak kullanılmıştır.

Geleneksel yapı ustalarının bilgi, beceri ve uygulamalarının incelenmesi, Doğu Karadeniz evlerinin yapım tekniklerinin belgelenmesinde önem taşımaktadır. Doğu Karadeniz evlerinin mimari özelliklerinin ve inşa tekniklerinin, yapı ustalarının bilgi ve becerileriyle birlikte değerlendirilmesi, restorasyonlarda kullanılacak teknik bilgilerin derlenmesi açısından da gereklidir. Bu kapsamda, hâlen yaşayan yapı ustalarının bulunması, bilgi ve becerilerinin mimari ve halkbilim yöntemlerinin bütüncül ve tamamlayıcı bir şekilde kullanımıyla belgelenmesi, bunun yanı sıra, geçmişte yaşayan ustaları konu alan belgesellerin, bu bütüncül bakış açısıyla değerlendirilmesi önemlidir. Bu bağlamda, bu çalışma, Doğu Karadeniz Evlerinin somut ve somut olmayan yönlerini birlikte ele alarak, farklı alanlarda yapılacak bütüncül belgeleme çalışmaları için tekrarlanabilir bir çalışma yöntemi paylaşmaktadır. Fakat bu yöntemin yeni çalışmalarda alan araştırmalarıyla zenginleştirilmesi, hâlen yaşayan yapı ustalarının bulunarak bilgi, beceri ve deneyimlerinin kayıt altına alınarak geleneksel yapı kültürünün somut ve somut olmayan yönlerinin birlikte belgelenmesi ve bütüncül koruma ve sürdürülebilirliklerine yönelik yaklaşımların geliştirilmesi gerekmektedir. 
Hakem Değerlendirmesi: Dış bağımsız.

Çıkar Çatışması: Yazar çıkar çatışması bildirmemiştir.

Finansal Destek: Yazar bu çalışma için finansal destek almadığını beyan etmiştir.

Peer-review: Externally peer-reviewed.

Conflict of Interest: The author has no conflict of interest to declare.

Grant Support: The author declared that this study has received no financial support.

\section{Kaynakça/References}

Akagawa Natsuko ve Tiamsoon Sirisrisak. "Intangible Heritage in Urban Planning Process, Case Study: Chao Phraya Riverscape, Thailand". The 8th International Asian Planning Schools Association Congress'de sunulan bildiri, Malezya, 11-14 Eylül 2005.

Aran, Kemal. Barınaktan Öte: Anadolu Kır Yapıları, Ankara: Tepe Mimarlık Kültürü Merkezi, 2000.

Arın, Süha. Sisler Kovulunca: Eski Evler, Eski Ustalar, Doğu Karadeniz. Belgesel Film, MTV, 1986. Erişim 28 Haziran 2021, https://www.youtube.com/watch?v=Ngu-6DgkEFg

Başkan, Seyfi. “Geleneksel Doğu Karadeniz Evleri”, Erdem-Atatürk Kültür Merkezi Dergisi 52 (2008): 41-90.

Eruzun, Cengiz. "Significance of Wood in Formation of Traditional Turkish Architecture and Eastern Black Sea Example". Proceedings of the 15th International Symposium of the IIWC'de sunulan bildiri, İstanbul, 20 Eylül, 2006, 11. Erişim 28 Haziran 2021, http://iiwc.icomos.org/assets/2006eruzun2.pdf

Güler, Koray ve Ayşe Ceren Bilge. "Doğu Karadeniz Ahşap Karkas Yapı Geleneği ve Koruma Sorunları”. Ahşap Yapılarda Koruma ve Onarım Sempozyumu 2 Bildiri Kitabı. İstanbul: İstanbul Büyükşehir Belediyesi, 2013, 65-80.

Güler, Koray. "Doğu Karadeniz Kırsal Mimarisi Örneklerinden Rize-Fındıklı Aydınoğlu Evi Restorasyon Projesi”. Yüksek Lisans Tezi, İstanbul Teknik Üniversitesi, 2012.

Ito, Nobuo. "Intangible Cultural Heritage involved in Tangible Cultural Heritage". ICOMOS 14th General Assembly and Scientific Symposium'da sunulan bildiri, Victoria Falls, Zimbabwe, 27-31 Ocak 2003. Erişim 28 Haziran 2021, http://openarchive.icomos.org/id/eprint/484/1/A3-2_-_Ito. pdf

Karakul, Özlem. “Kerpiç Mimaride Bezeme”, Yapı Dergisi 447 (2019): 64-71.

Karakul, Özlem. "A Conservation Approach to the Knowledge and Skills of Traditional Building Masters", Milli Folklor 107 (2015):149-160.

Karakul, Özlem. "An Integrated Methodology for the Conservation of Traditional Craftsmanship in Historic Buildings", International Journal of Intangible Heritage 10 (2015): 135-144.

Karakul, Özlem. "An Integrated Approach to Conservation Based on The Interrelations of Tangible and Intangible Cultural Properties". METU Journal of The Faculty of Architecture 28/2 (2011): 105-125.

Karakul, Özlem. "Folk Architecture in Historic Environments: Living Spaces for Intangible Cultural Heritage". Milli Folklor 75 (2007): 151-163.

Kuban, Doğan. Türk Ahşap Konut Mimarisi 17-19. Yüzyıllar. İstanbul: Türkiye İş Bankası Kültür Yayınları, 2017. 
Oğuz, Burhan. Türkiye Halkının Kültür Kökenleri-3| İnşa, Isıtma ve Aydınlatma Teknikleri. İstanbul: Anadolu Aydınlanma Vakfi Yayınları, 2001.

Özgüner, Orhan. Köyde Mimari: Doğu Karadeniz, Ankara: Apa Ofset Basimevi, 1970.

Pultar, Mustafa. "A Structured Approach to Cultural Studies of Architectural Space". Culture and Space in the Home Environment, Critical Evaluations and New Paradigms. Ed. S. Mete Ünügür, Orhan Hacıhasanoğlu ve Hülya Turgut, İstanbul: İTÜ Mimarlık Fakültesi, 1997, 27-32.

Sözen, Metin ve Cengiz Eruzun. Anadolu'da Ev ve Insan. Y.Y: Emlak Bankası Yayınları, 1992.

Sümerkan, Reşat. "Biçimlendiren Etkenler Açısından Doğu Karadeniz Kırsal Kesiminde Geleneksel Evlerin Yapı Özellikleri”. Doktora Tezi, Karadeniz Teknik Üniversitesi, 1990.

Sümerkan, Reşat. “Gelenekselden Betonarmeye Trabzon Kırsal Mimarlığı”, Mimarlık 234 (1989): 82-86.

Şimşek, Muhammed Salih. Derin Kökler-81.Bölüm. Belgesel Film, TRT, 2005. Erişim 28 Haziran 2021, https://www.youtube.com/watch?v=0C63Qx_mw9k

\section{Kaynak Kişiler}

Ali Yağc1, Yapı Ustası, Sisler Kovulunca (1986), Belgesel Film

Ali Rıza Alioğlu, Yapı Ustası, Sisler Kovulunca (1986), Belgesel Film

Ömer Keleşoğlu, Yapı Ustası, Sisler Kovulunca (1986), Belgesel Film

Müslüm ve İsmail Dilaver, Yapı Ustaları, Sisler Kovulunca (1986), Belgesel Film

Kasım Tavukçuoğlu, Yapı Ustası, Sisler Kovulunca (1986), Belgesel Film

Taştan Temur, Yapı Ustası, Sisler Kovulunca (1986), Belgesel Film 
